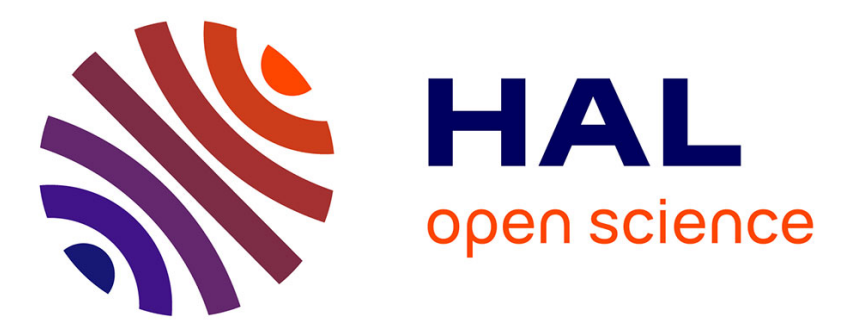

\title{
Novel green fatty acid-based bis-cyclic carbonates for the synthesis of isocyanate-free poly(hydroxyurethane amide)s
}

Lise Maisonneuve, Arvind S. More, Stéphanie Foltran, Carine Alfos, Frédéric Robert, Yannick Landais, Thierry Tassaing, Etienne Grau, Henri Cramail

\section{To cite this version:}

Lise Maisonneuve, Arvind S. More, Stéphanie Foltran, Carine Alfos, Frédéric Robert, et al.. Novel green fatty acid-based bis-cyclic carbonates for the synthesis of isocyanate-free poly(hydroxyurethane amide)s. RSC Advances, 2014, 4 (49), pp.25795-25803. 10.1039/c4ra03675a . hal-01366356

\section{HAL Id: hal-01366356 https://hal.science/hal-01366356}

Submitted on 22 Nov 2019

HAL is a multi-disciplinary open access archive for the deposit and dissemination of scientific research documents, whether they are published or not. The documents may come from teaching and research institutions in France or abroad, or from public or private research centers.
L'archive ouverte pluridisciplinaire HAL, est destinée au dépôt et à la diffusion de documents scientifiques de niveau recherche, publiés ou non, émanant des établissements d'enseignement et de recherche français ou étrangers, des laboratoires publics ou privés. 


\title{
Novel green fatty acid-based bis-cyclic carbonates for the synthesis of isocyanate-free poly(hydroxyurethane amide)s
}

\author{
Lise Maisonneuve ${ }^{\mathrm{a}, \mathrm{b}}$, Arvind S. More ${ }^{\mathrm{a}, \mathrm{b}}$, Stéphanie Foltran ${ }^{\mathrm{c}, \mathrm{d}}$, Carine Alfos ${ }^{\mathrm{e}}$, Fréderic Robert ${ }^{\mathrm{c}, \mathrm{d}}$, \\ Yannick Landais $^{\mathrm{c}, \mathrm{d}}$, Thierry Tassaing ${ }^{\mathrm{c}, \mathrm{d}}$, Etienne Grau ${ }^{\mathrm{a}, \mathrm{b}}$, Henri Cramail ${ }^{\mathrm{a}, \mathrm{b} *}$ \\ ${ }^{a}$ Centre National de la Recherche Scientifique, Laboratoire de Chimie des Polymères Organiques, UMR 5629, \\ IPB/ENSCBP, 16 avenue Pey-Berland, F-33607 Pessac Cedex, France, E-mail: cramail@enscbp.fr \\ ${ }^{b}$ Univ. of Bordeaux, Laboratoire de Chimie des Polymères Organiques, UMR 5629, IPB/ENSCBP, 16 avenue \\ Pey-Berland, F-33607 Pessac Cedex, France \\ ${ }^{c}$ Centre National de la Recherche Scientifique, Institut des Sciences Moléculaires, UMR 5255, 351, Cours de la \\ libération, 33405 Talence Cedex, France. \\ ${ }^{d}$ Univ. of Bordeaux, Institut des Sciences Moléculaires, UMR 5255, 351, Cours de la libération, 33405 Talence \\ Cedex,France \\ e ITERG, 11 rue Gaspard Monge, F-33600 Pessac Cedex, France
}

\begin{abstract}
Fatty acid-based bis-cyclic 5-membered carbonates containing amide linkages were prepared from methyl 10-undecenoate. The reaction in bulk of these bio-based carbonates with a series of di-amines led to poly(hydroxyurethane amide)s with molar masses up to 31000 g. $\mathrm{mol}^{-1}$. As expected, the soformed bio-based thermoplastic poly(hydroxyurethane)s exhibit amorphous to semi-crystalline features with respect to the chemical structure of the monomers used.
\end{abstract}

\section{Introduction}

Despite the interest of developing renewable diols (or polyols) ${ }^{1-4}$, the use of toxic (poly-) isocyanates, manufactured from amine and phosgene, remains a matter to settle in the chemistry of polyurethanes..$^{5-8}$ Therefore, the urge of finding alternative routes for the synthesis of PUs which avoid the use of isocyanate is of high importance. Several ways are considered to produce more sustainable non isocyanate polyurethanes (NIPU) from vegetable oil derivatives, such as: (i) the ring-opening of cyclic carbonates by amines ${ }^{9-11}$, (ii) the transurethane process ${ }^{12-15}$ and (iii) the self-condensation method based on the Curtius rearrangement in which the AB-type monomer contains both hydroxyl and acyl azide groups. ${ }^{16,17}$ The reaction of cyclic carbonates with amines has emerged as the most promising non-isocyanate route leading to poly(hydroxyurethane)s (PHUs). ${ }^{5,7,8}$ The PHUs present specific properties, in comparison to those of classical PUs, notably due to the presence of the hydroxyl functions generated along with the polymerization.

The 5-membered cyclic carbonate can be generated efficiently through functionalization of the triglyceride double bonds. The epoxidation/carbonation strategy is a well-known and efficient procedure to prepare 5-membered cyclic carbonates from olefins. Research groups have intensely investigated poly(hydroxyurethane) networks from carbonated vegetable oils. Only one example of 
fatty acid-based thermoplastic poly(hydroxyurethane) has been reported so far in the literature. ${ }^{18}$ Besides, the vegetable oil-based cyclic carbonates are usually bearing ester groups due to the inherent structure of the triglycerides. However, the occurrence of amidation side reactions has been demonstrated in some cases. ${ }^{7,19-21}$ For instance, Javni et al. clearly demonstrated that during the curing of the poly(hydroxyurethane) networks, the amine groups can react with the ester functions to form amide linkages. ${ }^{21}$ Hence, cyclic carbonate compounds without ester linkages would be favored.

This paper is thus dedicated to the design of novel fatty acid-based bis-cyclic carbonates bearing mainly amide linkages in their structure with the idea to prepare non-isocyanate and nonphosgene thermoplastic poly(hydroxyurethane amide)s with high molar masses and glass transition temperatures. FTIR-ATR, NMR, SEC and DSC were performed to investigate the PHUs chemical structures, molar masses, thermal properties and thermal stabilities.

\section{Monomer synthesis}

To synthesize linear PHUs from fatty acid derivatives, five bis-cyclic carbonates were prepared starting from methyl undecenoate by (i) transesterification and/or amidation followed by (ii) epoxidation and (iii) carbonation reaction. The Figure 1 illustrates the chemical structures of the synthesized bis-cyclic carbonates. The spacers of the cyclic carbonate dimers were of different nature so as to design PHUs with different thermal properties. One cyclic carbonate dimer presents two ester groups (UndPdE-b5CC) and the others have two amide linkages. Amide functions were introduced into the cyclic carbonates owing to their ability to form strong hydrogen bonds and also to replace ester functions, which can lead to side reactions during polymerization. Among the diamide bis-cyclic carbonates, UndBdA-b5CC is issued from butane-1,4-diamine, which allows the formation of hydrogen bonds with the CONH group. In order to obtain diamide bis-cyclic carbonates with lower melting point, piperazine (UndPipdA-b5CC), N,N'-dimethylpropane-1,3-diamine (UndPMedA-b5CC) and N,N'-dihexyldecane-1,10-diamine (UndDHexdA-b5CC) were used as spacers. As it has been reported in literature that internal cyclic carbonates were less reactive than terminal ones ${ }^{18}$, methyl undecenoate was thus preferred as starting material. The chemical structure of the synthesized cyclic carbonates dimers and intermediates were evaluated by ${ }^{1} \mathrm{H}$ and ${ }^{13} \mathrm{C}$ NMR and FTIR-ATR spectroscopies. 

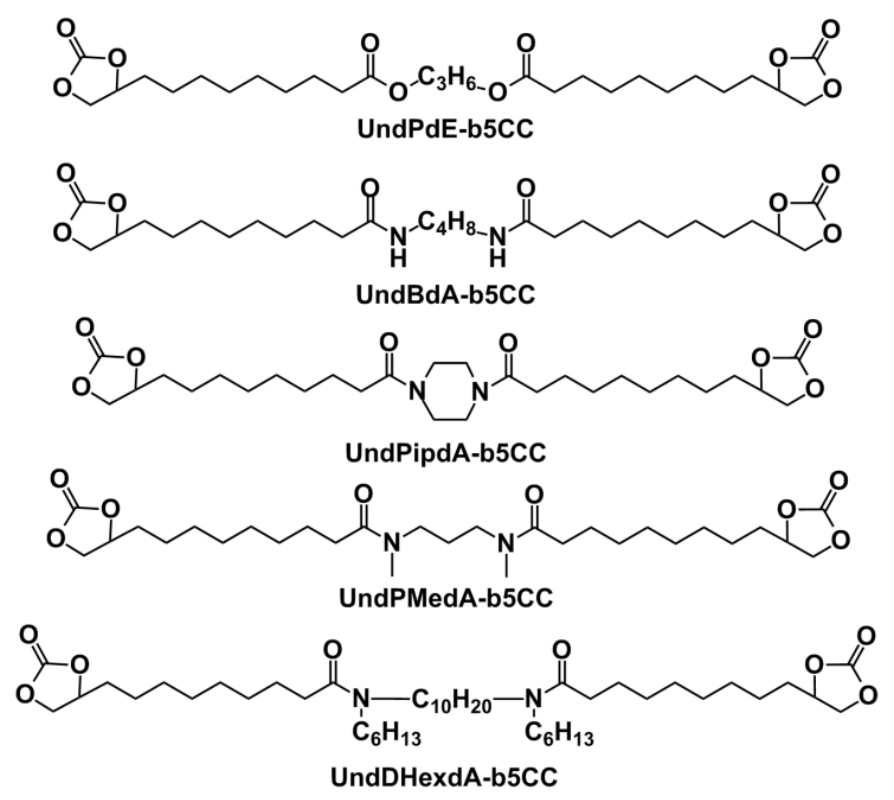

Figure 1-Chemical structures of the synthesized cyclic carbonates dimers. Abbreviations used are as follows: $[$ Und $=$ from methyl undecenoate $] ;[P=$ propyl, $B=$ butyl, Pip=from piperazine, $P M e=$ from $N, N^{\prime}$-dimethylpropane-1,3-diamine, DHex=from $N, N$ '-dihexyldecane-1,10-diamine $] ;[d=d i$ - $]$ and $[E=$ ester, $A=$ amide, b5CC=bis 5-membered cyclic carbonate $]$.

The Scheme 1 illustrates the synthesis of UndBdA-b5CC from methyl undecenoate and butane-1,4-diamine (see ESI for the synthesis of UndPdE-b5CC). The syntheses of UndPipdA-b5CC, UndPMedA-b5CC and UndDHexdA-b5CC have been carried out in the same way with slight variations of the catalyst quantity, the solvent, the temperature and the pressure (see ESI).

In the specific case of UndDHexdA-b5CC, the N,N'-dihexyldecane-1,10-diamine (SebHex-diamine) was first prepared by the reduction of the corresponding diamide, itself obtained from sebacoyl chloride and hexylamine. Then, the reaction between SebHex-diamine and methyl undecenoate was investigated but no conversion was observed probably due to the lower reactivity of the SebHex-diamine. This observation led to the use of more reactive undecenyl chloride instead of methyl undecenoate.

In all cases, the amidation reactions were monitored by means of FTIR-ATR and ${ }^{1} \mathrm{H}$ NMR spectroscopies (see ESI). IR spectroscopy of UndBdA showed two absorption bands at $1630 \mathrm{~cm}^{-1}$ and $1540 \mathrm{~cm}^{-1}$, whereas, as expected, UndPipdA, UndPMedA and UndDHexdA FTIR-ATR spectra presents only the amide carbonyl stretching vibration in the range $1650 \mathrm{~cm}^{-1}-1640 \mathrm{~cm}^{-1}$. The ester carbonyl stretching $(\underline{\mathrm{O}=\mathrm{C}}-\mathrm{O})$ of the methyl undecenoate at $1720 \mathrm{~cm}^{-1}$ disappeared during all diamide syntheses. The UndBdA displayed also a band at $3295 \mathrm{~cm}^{-1}$ characteristic of N-H stretching vibrations (see ESI). When necessary, the diamide was purified by flash chromatography to remove the unreacted methyl undecenoate and the monoamide formed. 


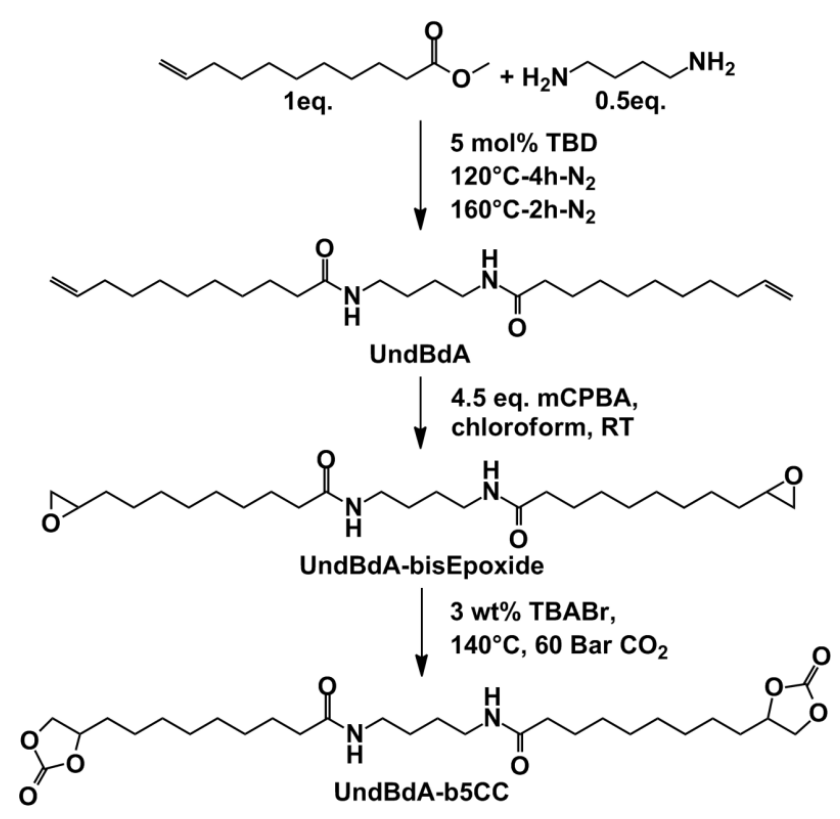

Scheme 1- Synthetic strategy to UndBdA-b5CC from methyl undecenoate, butane-1,4-diamine and $\mathrm{CO}_{2}$.

As an example, the stacked ${ }^{1} \mathrm{H}$ NMR spectra of the different steps for the synthesis of UndPipdA-b5CC are given in Figure 2. The formation of the amide functions was confirmed in ${ }^{1} \mathrm{H}$ $\mathrm{NMR}$, by the appearance of a triplet at $2.32 \mathrm{ppm}$, corresponding to the protons nearby the $(\mathrm{C}=\mathrm{O}) \mathrm{NH}$ group. Moreover, the singlet at $3.66 \mathrm{ppm}$, which is characteristic of the ester moiety of methyl undecenoate, has disappeared.

(1)<smiles>C=CCCCCCCCCC(=O)N1CCN(C(=O)CCC(C)CCCC)CC1</smiles>

(2)

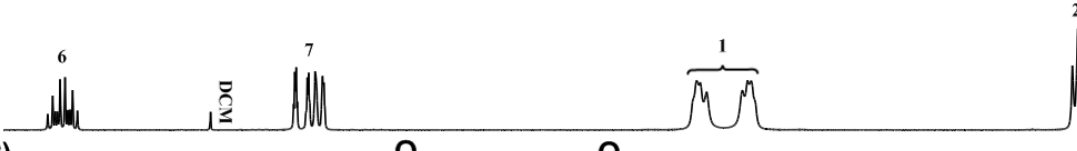<smiles>CC(CCC(C)CC1CO1)CCC(C)C(=O)N1CCN(C(=O)CCCCCCCCC2CC2)CC1</smiles>
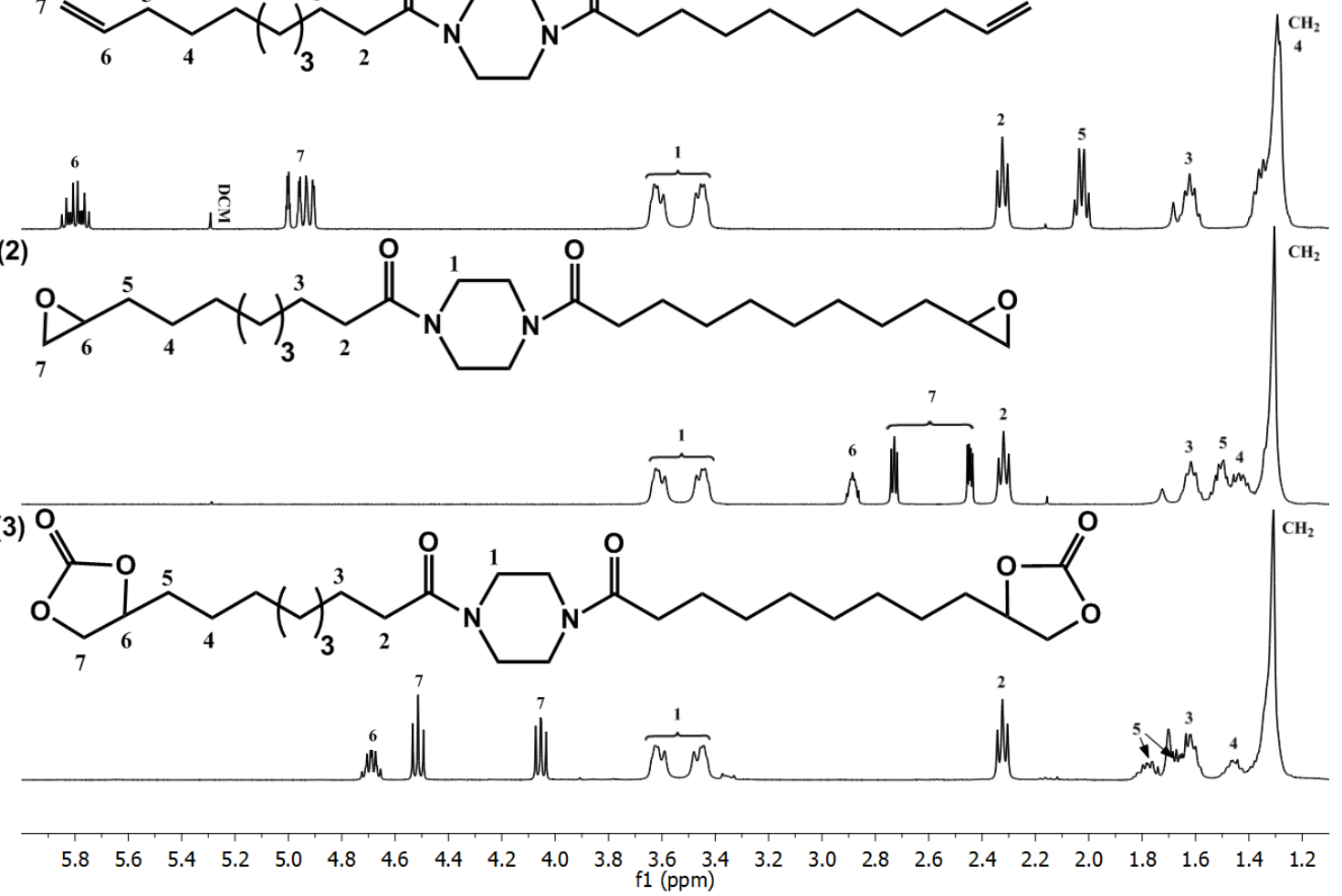

Figure 2- Stacked ${ }^{1} H$ NMR spectra of (1) UndPipdA, (2) UndPipdA-bisEpoxide and (3) UndPipdAb5CC. (Analyses in $\mathrm{CDCl}_{3}$ at room temperature) 
The epoxidation reactions of the bis-unsaturated precursors were performed with m-CPBA (meta-chloroperoxybenzoic acid) according to the previous literature. ${ }^{18}$ The reaction progress was followed by the disappearance of olefinic protons by ${ }^{1} \mathrm{H}$ NMR spectroscopy. The synthesis of the epoxide was attested by the formation of the epoxide characteristic peaks, e.g. multiplets at $2.88 \mathrm{ppm}$, $2.73 \mathrm{ppm}$ and $2.45 \mathrm{ppm}$ (protons $\mathrm{H} 6$ and $\mathrm{H} 7$ ). After completion of the epoxidation, the reaction mixture was then successively washed with aqueous sodium sulfite, aqueous sodium bicarbonate and water to remove excess of m-CPBA.

Various reaction conditions have been used for the carbonation of epoxide. After in-situ FTIR investigations to monitor the kinetics of the carbonation reaction, ${ }^{22-24}$ (See ESI) the following procedure has been chosen. After 24 hours, full conversion was attained for all fatty acid-based bis epoxides using the following reaction conditions: $80^{\circ} \mathrm{C} / 50$ Bar for UndPdE-bisEpoxide, UndPMedAbisEpoxide bis-epoxide and UndPipdA-b5CC clearly demonstrates the formation of the cyclic carbonate. (See protons H6 and UndDHexdA-bisEpoxide, $135^{\circ} \mathrm{C} / 50$ Bar for UndPipdA-bisEpoxide and $140^{\circ} \mathrm{C} / 60 \mathrm{Bar}$ for UndBdA-bisEpoxide.

After carbonation reactions, a band in the range $1795 \mathrm{~cm}^{-1}-1775 \mathrm{~cm}^{-1}$, corresponding to the carbonyl vibration of the cyclic carbonate was visible for all synthesized 5-membered cyclic carbonates. (See ESI) The formation of the cyclic carbonate was also confirmed by ${ }^{1} \mathrm{H}$ NMR (see ESI) For instance, the ${ }^{1} \mathrm{H}$ NMR spectra of UndPipdA-b5CC is given in Figure 2-(3). (see H6 and H7)

The purity (when possible) and melting points of the monomers, as well as the HSQC (Heteronuclear single quantum coherence)-NMR analysis for UndPipdA-b5CC are given in ESI. Amide-containing cyclic carbonates showed higher melting points than UndPdE-b5CC. While removing the possibility of $\mathrm{H}$-bond formation and bringing flexibility thanks to pendent groups/chains to the spacer, lower melting points were observed. The global yields over the three steps were in accordance with green chemistry (see Table 1 in ESI) and syntheses on several grams scale were achievable.

\section{Poly(hydroxyurethane amide)s}

To prepare a wide range of fatty acid-based isocyanate-free PHUs, the synthesized bis-cyclic carbonates were used in polyaddition processes with four diamines; butane-1,4-diamine (4DA), isophorone diamine (IPDA), the Priamine 1075 (a dimer of fatty acid from CRODA) and Jeffamine 400 (an amino-telechelic polyether with a molar mass of 400 g.mol ${ }^{-1}$ ). The diamines IPDA, Priamine 1075 and Jeffamine 400 were used to introduce flexibility in the PHUs, by increasing the free volume between the polymer chains. The Scheme 2 illustrates the synthesis of PHUs. First, polymerization tests were carried out in solvent, but the reactions were really too slow. Polymerizations were then performed in bulk, thus avoiding further treatment to recover the solvent. Thus, polyadditions were carried out at a temperature depending on the melting point of the bis-cyclic carbonate used; $140^{\circ} \mathrm{C}$ (for UndBdA-b5CC and UndPipdA-b5CC), $120^{\circ} \mathrm{C}$ (for UndPMedA-b5CC and UndDHexdA-b5CC) 
and $70^{\circ} \mathrm{C}$ or $110^{\circ} \mathrm{C} / 120^{\circ} \mathrm{C}$ for UndPdE-b5CC). The potential catalysis of the reaction was also investigated (see ESI) and none of them show dramatic improvement as compared to a catalyst-free polymerization.

Even at high temperature, the blends were not fully homogeneous while using UndBdA-b5CC or IPDA, due to the hydrogen bonds and cyclo-aliphatic structure of the monomers used. The polymerizations were monitored with FTIR-ATR. PHUs were obtained as brown to yellow viscous to solid compounds. 
Table 1 gives the experimental details along with the abbreviations used for the PHUs, as well as the polymerizations results.
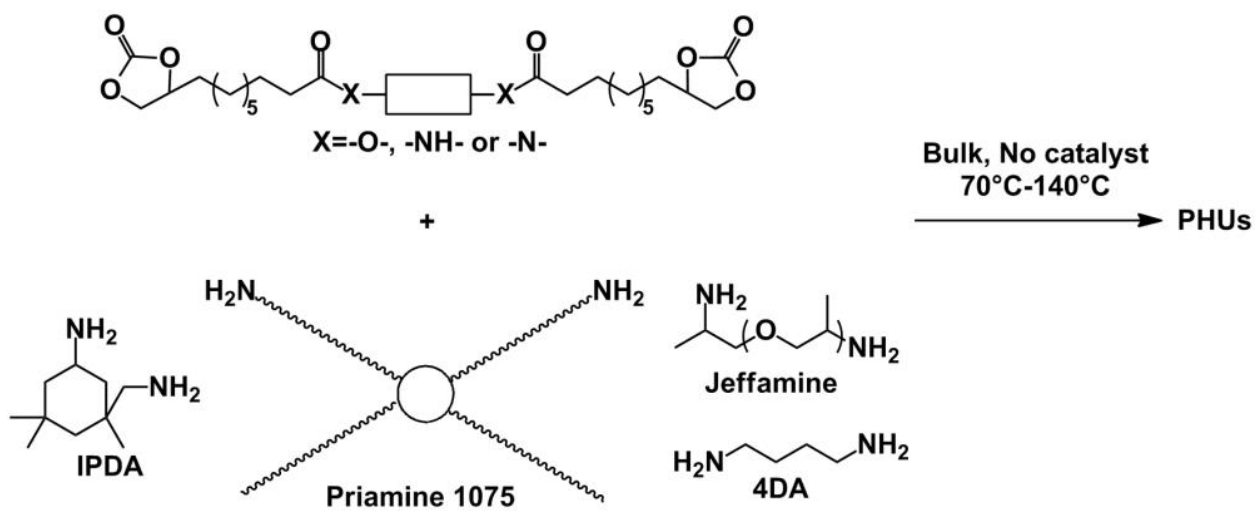

Scheme 2- Synthesis of fatty acid-based poly(hydroxyurethane)s

The polymer chemical structures were assessed by FTIR-ATR and ${ }^{1} \mathrm{H}$ NMR spectroscopies. The appearance of bands around $1700 \mathrm{~cm}^{-1}$ and $1540 \mathrm{~cm}^{-1}$, corresponding to the vibrations of $\underline{\mathrm{C}=\mathrm{O}}-\mathrm{NH}$ and $\mathrm{CN}$ respectively, attested to the formation of urethane linkage. Besides, a large band attributed to the $\mathrm{NH}$ and $\mathrm{OH}$ vibrations were observed in the region $3660 \mathrm{~cm}^{-1}-3120 \mathrm{~cm}^{-1}$. The ester and amide moieties of the bis-cyclic carbonate precursor were well-preserved even at high temperature. The FTIR-ATR spectra of PHU-BdA-1, PHU-PipdA-1, PHU-PMedA-1 and PHU-DHexdA-1 are given in ESI. As illustrated in Figure 3, the synthesis of PHU was assessed by ${ }^{1} \mathrm{H}$ NMR by the formation of a clearly visible peak at $3.15 \mathrm{ppm}$. Besides, the peaks corresponding to the cyclic carbonates decreased with conversion. The signals corresponding to the hydroxyl urethanes could be attributed that revealed the balanced formation (50:50) of primary and secondary alcohols. As an example, for PHU-PipdA-2, the ratio between the formation of primary and secondary alcohols was 43.8:56.2 (see Figure 3). Concerning the potential side reaction between the amine and the ester or amide functions, ${ }^{1} \mathrm{H}$ NMR of PHU-PipdA-2 testified that no transamidification took place during the polymerization. It can be noticed from 
Table 1 that conversions were relatively fast and reached values of $60 \%-95 \%$ after 5 hours. The polymerizations with Priamine 1075 were much faster than with IPDA and Jeffamine, probably due to the unhindered character of the amine.

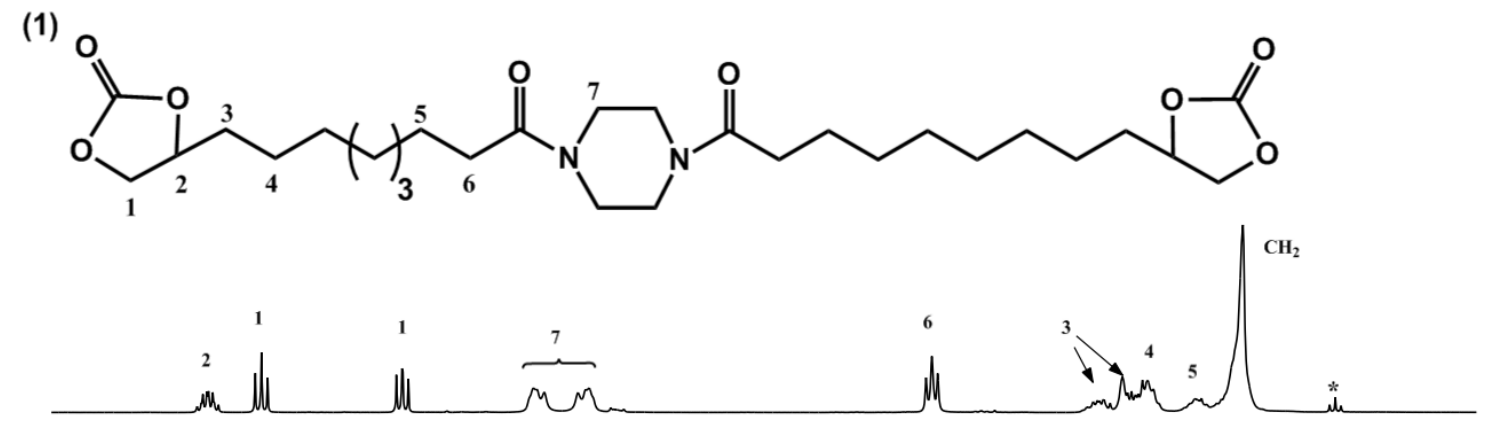

(2)

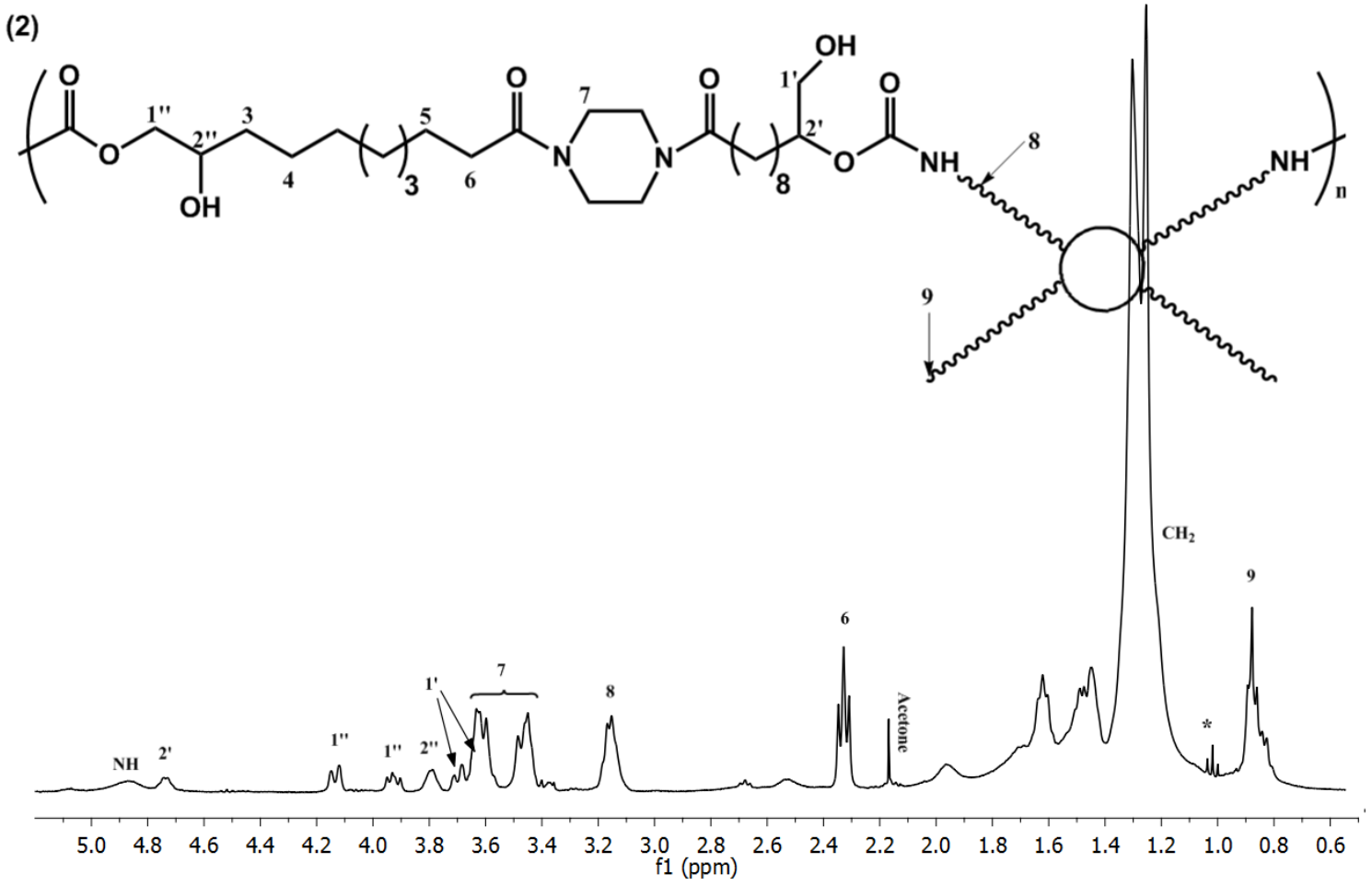

Figure 3- Stacked ${ }^{1} \mathrm{H}$ NMR spectra of PHU-PipdA-2. ${ }^{(*)} \mathrm{TBABr}$. (Analyses in $\mathrm{CDCl}_{3}$ )

SEC data, which are exposed in 
Table 1, indicate the formation of PHUs with molar masses in the range 11000 to 31000 g. $\mathrm{mol}^{-1}$. However, the molar mass values provided by SEC should not be taken as absolute values as the SEC calibration was carried out in DMF using PS standards. (see ESI for SEC analysis of PHU-PMedA-2). The molar mass dispersities were in the range of 1.2 to 2.9. The molar masses data given in 
Table 1 correspond to the main peak observable in SEC. However, in almost all analyses, a smaller peak around 4000 g.mol ${ }^{-1}$ can be detected and could be attributed to the presence of cycles. 
Table 1-Molar masses and dispersities of the PHUs from 5-membered cyclic carbonate dimers and diamines polymerized in bulk.

\begin{tabular}{|c|c|c|c|c|c|c|c|}
\hline Sample & Used b5CC & Diamine & Temperature $\left({ }^{\circ} \mathrm{C}\right)$ & Time & $\begin{array}{c}\text { Conversion } \\
(\%)^{1}\end{array}$ & $\bar{M}_{\mathrm{m}}\left(\mathrm{g} \cdot \mathrm{mol}^{-1}\right)^{2}$ & $\oplus^{2}$ \\
\hline \multirow[t]{3}{*}{ PHU-dE-1 } & UndPdE-b5CC & $4 \mathrm{DA}$ & 70 & $1 \mathrm{~d}$ & 95.1 & 25400 & 1.6 \\
\hline & & & & $3 d$ & 95.6 & 29800 & 1.8 \\
\hline & & & & $7 d$ & 96.4 & 30400 & 2.5 \\
\hline \multirow{2}{*}{ PHU-BdA-1 } & UndBdA-b5CC & IPDA & 140 & $5 \mathrm{~h}$ & 64.1 & 15300 & 1.3 \\
\hline & & & & $13 d$ & 97.6 & 18900 & 2.4 \\
\hline PHU-BdA-2 & & priamine & 140 & $5 \mathrm{~h}$ & 97.6 & 14900 & 1.5 \\
\hline \multirow[t]{2}{*}{ PHU-BdA-3 } & & Jeffamine & 140 & $5 \mathrm{~h}$ & 84.3 & 14600 & 1.3 \\
\hline & & & & $6 d$ & 98.9 & 20900 & 2.6 \\
\hline \multirow[t]{2}{*}{ PHU-PipdA-1 } & UndPipdA-b5CC & IPDA & 140 & $5 \mathrm{~h}$ & 76.3 & 16500 & 1.5 \\
\hline & & & & $1 d$ & 87.0 & 18200 & 1.5 \\
\hline \multirow[t]{2}{*}{ PHU-PipdA-2 } & & priamine & 140 & $5 \mathrm{~h}$ & 91.9 & 19300 & 1.7 \\
\hline & & & & $1 d$ & 93.2 & 19200 & 1.7 \\
\hline \multirow[t]{2}{*}{ PHU-PipdA-3 } & & Jeffamine & 140 & $5 \mathrm{~h}$ & 46.7 & 11200 & 1.2 \\
\hline & & & & $3 d$ & 91.5 & 23300 & 2.9 \\
\hline \multirow[t]{2}{*}{ PHU-PMedA-1 } & UndPMedA-b5CC & IPDA & 120 & $5 \mathrm{~h}$ & 53.5 & 11000 & 1.2 \\
\hline & & & & $12 d$ & 91.5 & 31100 & 2.2 \\
\hline \multirow[t]{2}{*}{ PHU-PMedA-2 } & & priamine & 120 & $5 \mathrm{~h}$ & 87.6 & $\mathrm{~mm}^{3}$ & $\mathrm{~mm}^{3}$ \\
\hline & & & & $6 d$ & 94.4 & 28700 & 1.7 \\
\hline \multirow[t]{2}{*}{ PHU-PMedA-3 } & & Jeffamine & 120 & $5 \mathrm{~h}$ & 12.4 & $\mathrm{~mm}^{3}$ & $\mathrm{~mm}^{3}$ \\
\hline & & & & $6 d$ & 84.1 & 20700 & 1.4 \\
\hline PHU-DHexdA-1 & UndDHexdA- & IPDA & 120 & $1 d$ & $\mathrm{~ns}$ & $\mathrm{~ns}$ & $\mathrm{~ns}$ \\
\hline PHU-DHexdA-2 & & priamine & 120 & $1 d$ & nd & nd & nd \\
\hline PHU-DHexdA-3 & & Jeffamine & 120 & $1 d$ & nd & nd & nd \\
\hline PHU-DHexdA-4 & & $4 \mathrm{DA}$ & 120 & $1 \mathrm{~d}$ & nd & nd & nd \\
\hline
\end{tabular}

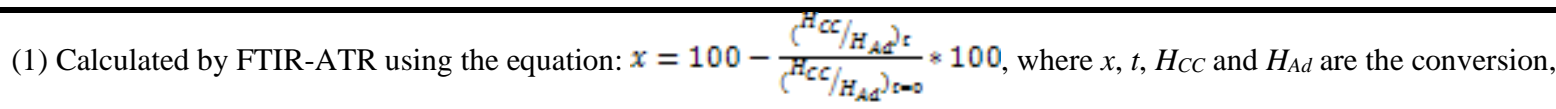

the time, the height of the peaks corresponding to the cyclic carbonate and amide (or ester) carbonyls respectively. (2) SEC in DMF with $1 \mathrm{wt} \% \mathrm{LiBr}$ - calibration PS standards. The analyses were performed on the soluble fraction. The given data correspond to the main peak in SEC. The results presented here are for the fraction at $5 \mathrm{~h}$ and for the best molar masses fraction or the last soluble fraction observed for each sample. (3) Highly multi modal molar masses. ns=not soluble and nd=not determined.

The fatty acid-based cyclic carbonate dimers demonstrate low reactivity, even at high temperatures. Indeed cyclic carbonates are known to be stabilize by the $+\mathrm{I}$ inductive effect of the alkyl chain. ${ }^{25,26}$ Thus, no full conversions were achieved even after long polymerization times. Moreover, after long times at high temperature, side reactions started to occur. In FTIR-ATR, those side reactions could be attributed to ester or dialkyl carbonate formation. (see ESI for PHU-PMedA-2) The appearance of side reactions are in good agreement with slight decreases of the molar masses and of the glass transition temperatures. (see ESI). 


\section{Thermal properties}

The thermal properties of the synthesized PHUs are well correlated with their chemical structure. Table 2 summarized the glass transition and melting temperatures of the PHUs. Amorphous PHUs were obtained with UndPipdA-b5CC, UndPMedA-b5CC and UndDHexdA-b5CC. The cyclic structure of the spacer of UndPipdA-b5CC led to higher Tg. Moreover, the longer the alkyl dangling group or chain, the lower the glass transition. (See PHU-PipdA-1, PHU-PMedA-1 and PHU-DHexdA1 in Figure 4) The use of a cyclic aliphatic amine induced the formation of a PHU with a glass transition temperature of $39.9^{\circ} \mathrm{C}$. However, while using Priamine, a lower glass transition temperature $\left(2.4^{\circ} \mathrm{C}\right)$ was obtained. Indeed, the resulting dangling chains in the polymer backbone, plasticizes the so-formed PHU. The PHU-BdA-3 with Jeffamine (400 g.mol $\left.{ }^{-1}\right)$ as a co-monomer reached an even lower glass transition of $-21^{\circ} \mathrm{C}$, which can be explained by the polyether nature of the Jeffamine.

Table 2- Thermal properties of the synthesized PHUs.

\begin{tabular}{cccc}
\hline Sample & Time & $\mathrm{T}_{\mathrm{g}}\left({ }^{\circ} \mathrm{C}\right)^{1}$ & $\mathrm{~T}_{\mathrm{m}}\left({ }^{\circ} \mathrm{C}\right)^{1}$ \\
\hline PHU-dE-1 & $1 \mathrm{~d}$ & -17 & - \\
\hline PHU-BdA-1 & $13 \mathrm{~d}$ & 40 & $115^{2}$ \\
PHU-BdA-2 & $6 \mathrm{~d}$ & 2 & 115 \\
PHU-BdA-3 & $6 \mathrm{~d}$ & -21 & 109 \\
\hline PHU-PipdA-1 & $6 \mathrm{~d}$ & 55 & - \\
PHU-PipdA-2 & $1 \mathrm{~d}$ & -2 & - \\
PHU-PipdA-3 & $6 \mathrm{~d}$ & -15 & - \\
\hline PHU-PMedA-1 & $6 \mathrm{~d}$ & 32 & - \\
PHU-PMedA-2 & $1 \mathrm{~d}$ & -4 & - \\
PHU-PMedA-3 & $6 \mathrm{~d}$ & -17 & - \\
\hline PHU-DHexdA-1 & $6 \mathrm{~d}$ & 3 & - \\
PHU-DHexdA-2 & $1 \mathrm{~d}$ & -18 & - \\
PHU-DHexdA-3 & $6 \mathrm{~d}$ & -29 & - \\
PHU-DHexdA-4 & $1 \mathrm{~d}$ & -13 & -
\end{tabular}

(1) Determined by DSC at $10^{\circ} \mathrm{C} \cdot \mathrm{min}^{-1}$. (2) With crystallization upon heating. 


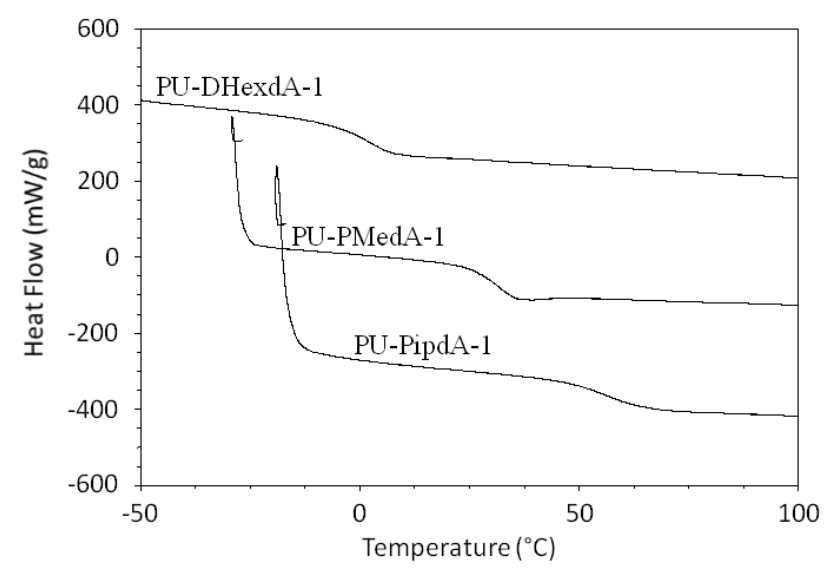

Figure 4- DSC traces of amorphous PHU-PipdA-1, PHU-PMedA-1 and PHU-DHexdA-1.

With UndBdA-b5CC as a co-monomer, the PHUs obtained were semi-crystalline in nature. The presence of hydrogen bonds from the amide linkages of UndBdA-b5CC favored interactions between polymer chains and thus the crystallization of the resulting PHUs. The effect of the chemical structure of the diamine can be observed in Figure 5 with UndBdA-b5CC. Figure 5 shows the DSC traces of the semi-crystalline PHUs based on UndBdA-b5CC with various diamines.

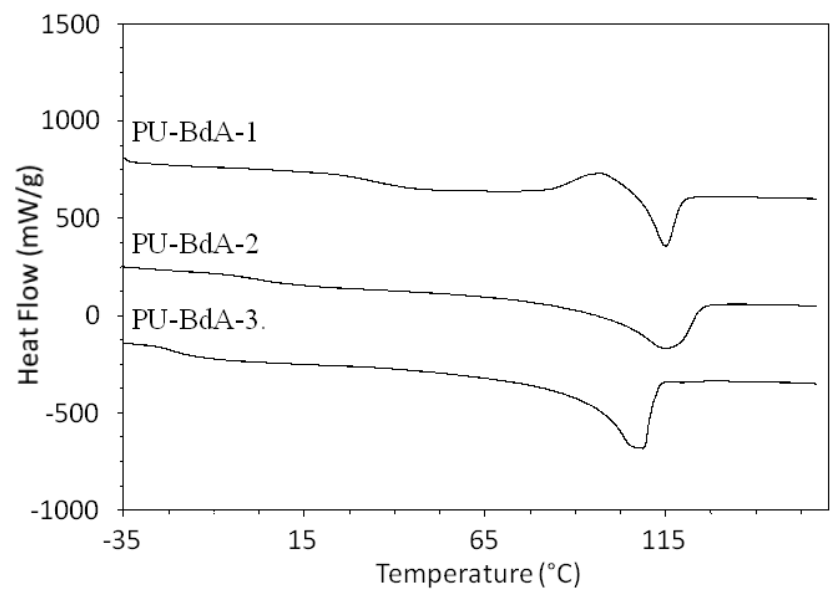

Figure 5- DSC thermograms after second heating of semi-crystalline PHU-BdA-1, PHU-BdA-2 and PHU-BdA-3.

\section{Experimental methods}

\section{Synthesis and characterizations of cyclicarbonates and their polyyhydroxyurethane}

\section{1- Transesterification and amidation reactions}

Transesterification step. Methyl undecenoate (20 g, $101 \mathrm{mmol})$, propanediol (3.8 g, $50 \mathrm{mmol})$, TBD (702 mg, $5 \mathrm{mmol})(1: 0.5: 0.05)$ were stirred under nitrogen flow at $120^{\circ} \mathrm{C}(4 \mathrm{~h})$, at $160^{\circ} \mathrm{C}(2 \mathrm{~h})$ then 
under vacuum at $160^{\circ} \mathrm{C}(30 \mathrm{~min})$. The reaction mixture was dissolved in ethyl acetate $(200 \mathrm{~mL})$ and washed with water $(3 \times 50 \mathrm{~mL})$. The organic layer was dried over anhydrous sodium sulfate, filtered and solvent was removed on rotary evaporator. Yield $=73 \%$. UndPdE: ${ }^{1} \mathrm{H} \mathrm{NMR}\left(\mathrm{CDCl}_{3}, 25^{\circ} \mathrm{C}, 400\right.$ MHz) $\delta(\mathrm{ppm}): 5.78(\mathrm{~m}, 2 \mathrm{H}), 4.93(\mathrm{~m}, 4 \mathrm{H}), 4.12(\mathrm{t}, 4 \mathrm{H}), 2.27(\mathrm{t}, 4 \mathrm{H}), 2.02(\mathrm{~m}, 4 \mathrm{H}), 1.93(\mathrm{~m}, 2 \mathrm{H}), 1.59$ (m, 4H), 1.34 (m, 4H), 1.26 (m, 16H). IR ( $\left.\mathrm{cm}^{-1}\right): 2924,2853,1735,1161,906$.

Amidation step. The diamides were prepared with different method according to the chemical structure of the diamine.

Methyl undecenoate $(20 \mathrm{~g}, 101 \mathrm{mmol})$, butane-1,4-diamine $(4.4 \mathrm{~g}, 50 \mathrm{mmol})$ and TBD $(702 \mathrm{mg}, 5$ mmol) (1: 0.5: 0.05$)$ were stirred under nitrogen flow at $120^{\circ} \mathrm{C}(4 \mathrm{~h})$ then at $160^{\circ} \mathrm{C}(2 \mathrm{~h})$. The reaction flask was cooled down at $90^{\circ} \mathrm{C}$ and NMP $(60 \mathrm{~mL})$ was added to end up with an homogeneous phase. The required UnddA was slowly precipitated by reaching room temperature. A filtration and washes with methanol were performed. Yield $=83 \%$. UndBdA: ${ }^{1} \mathrm{H}$ NMR $\left(\mathrm{CDCl}_{3}, 50^{\circ} \mathrm{C}, 400 \mathrm{MHz}\right) \delta(\mathrm{ppm})$ : $5.79(\mathrm{~m}, 2 \mathrm{H}), 4.98(\mathrm{~m}, 4 \mathrm{H}), 3.26(\mathrm{~m}, 4 \mathrm{H}), 2.15(\mathrm{t}, 4 \mathrm{H}), 1.99(\mathrm{~m}, 4 \mathrm{H}), 1.65$ (m, 4H), 1.53 (m, 4H), 1.40 (m, 4H), 1.32 (m, 16H). IR ( $\left.\mathrm{cm}^{-1}\right): 3295,2918,2847,1630,1537$.

For UndPipdA and UndPMedA diamides, the amidation reactions were as followed. Methyl undecenoate, diamine and TBD (1: 0.5: 0.05) were stirred in a round-bottom flask equipped with a bubbling system under inert atmosphere at $100^{\circ} \mathrm{C}(2 \mathrm{~h})$, then under nitrogen flow at $120^{\circ} \mathrm{C}(4 \mathrm{~h})$ and at $160^{\circ} \mathrm{C}(2 \mathrm{~h})$. The diamides were purified by column chromatography and obtained as a yellow viscous liquid.

UndPipdA: Methyl undecenoate (20 g, $101 \mathrm{mmol})$, piperazine (4.3 g, $50 \mathrm{mmol})$ and TBD (702 mg, 5 mmol). UndPipdA was purified by column chromatography to eliminate completely the monoamide (eluent: cyclohexane / ethyl acetate with increasing percentage of ethyl acetate from $20 \%$ to 60\%). Yield $=68.2 \% .{ }^{1} \mathrm{H}$ NMR $\left(\mathrm{CDCl}_{3}, 25{ }^{\circ} \mathrm{C}, 400 \mathrm{MHz}\right) \delta(\mathrm{ppm}): 5.79(\mathrm{~m}, 2 \mathrm{H}), 4.94(\mathrm{~m}, 4 \mathrm{H}), 3.62(\mathrm{~m}$, 4H), $3.44(\mathrm{~m}, 4 \mathrm{H}), 2.32(\mathrm{t}, 4 \mathrm{H}), 2.03(\mathrm{~m}, 4 \mathrm{H}), 1.63(\mathrm{~m}, 4 \mathrm{H}), 1.35-1.29(\mathrm{~m}, 20 \mathrm{H}) . \mathrm{IR}\left(\mathrm{cm}^{-1}\right): 2918$, 2847, 1650, 906 .

UndPMedA: Methyl undecenoate (20 g, $101 \mathrm{mmol})$, N,N'-dimethylpropane-1,3-diamine $(5.2 \mathrm{~g}, 50$ $\mathrm{mmol}$ ) and TBD (702 mg, $5 \mathrm{mmol}$ ). UndPMedA was purified by column chromatography to eliminate completely the monoamide (eluent: heptane / ethyl acetate with increasing percentage of ethyl acetate from $20 \%$ to $60 \%)$. Yield $=79.3 \% .{ }^{1} \mathrm{H}$ NMR $\left(\mathrm{CDCl}_{3}, 25{ }^{\circ} \mathrm{C}, 400 \mathrm{MHz}\right) \delta(\mathrm{ppm}): 5.80(\mathrm{~m}, 2 \mathrm{H}), 4.95$ (m, 4H), 3.35-3.25 (m, 4H), 2.98-2.89 (s, 6H), $2.26(\mathrm{~m}, 4 \mathrm{H}), 2.01(\mathrm{~m}, 4 \mathrm{H}), 1.75(\mathrm{~m}, 2 \mathrm{H}), 1.59(\mathrm{~m}, 4 \mathrm{H})$, 1.34-1.28 (m, 20H). IR $\left(\mathrm{cm}^{-1}\right): 2924,2850,1639,906$.

Concerning the preparation of UndDHexdA, the diamine (SebHex-diamine) used as central block was synthesized in a first step, and then the amidation was performed. The SebHex-diamine was obtained by the reduction of the corresponding diamide issued from sebacoyl chloride and hexylamine. Hexylamine (9 g, $86.4 \mathrm{mmol}, 2.05$ eq.), triethylamine (20.7 mL, $143.3 \mathrm{mmol}, 3.41$ eq.), then chloroform $(125 \mathrm{~mL})$ were introduced in a round-bottom flash. Afterwards, the sebacoyl chloride (10 g, $42 \mathrm{mmol}, 1$ eq.) was added dropwise. The formation of a white precipitate due to the generation of 
triethylamine hydrochloride salt revealed the progress of the reaction. After filtration and washes with hot water, the organic phase was dried over anhydrous sodium sulfate, filtered and the chloroform was removed on rotary evaporator. After drying, the diamide was reduced by $\mathrm{LiAlH}_{4}$ (3 eq. per function) in dried THF under reflux overnight. Then, an aqueous solution of potassium sodium tartrate at $1 \mathrm{~mol} . \mathrm{L}^{-1}$ $(200 \mathrm{~mL})$ was added to the reaction mixture placed into an ice bath. The SebHex-diamine was recovered after filtration followed by extraction of the filtrate with ethyl acetate. SebHex-diamine was purified by column chromatography (eluent: ethyl ether / methanol with increasing percentage of methanol from $0 \%$ to $31 \%)$. Yield $=84.6 \%$. SebHex-diamine: ${ }^{1} \mathrm{H} \mathrm{NMR}\left(\mathrm{CDCl}_{3}, 25{ }^{\circ} \mathrm{C}, 400 \mathrm{MHz}\right) \delta$ (ppm): 2.57 (1, 8H), $1.46(\mathrm{~m}, 8 \mathrm{H}), 1.27(\mathrm{~m}, 24 \mathrm{H}), 0.81(\mathrm{t}, 6 \mathrm{H})$.

To SebHex-diamine $(8.4 \mathrm{~g}, 25 \mathrm{mmol})$, dried THF $(100 \mathrm{~mL})$ and triethylamine $(5.5 \mathrm{~g}, 55 \mathrm{mmol}, 1.1$ eq.) were added. Then undecenyl chloride (10 g, $49 \mathrm{mmol})$ was added dropwise. The reaction mixture was then stired at room temperature for 2 hours. UndDHexdA was purified by filtration of the formed salt, followed by column chromatography to eliminate completely the monoamide (eluent: heptane / ethyl acetate (95/5)). Yield $=91.3 \%$. UndDHexdA: ${ }^{1} \mathrm{H} \mathrm{NMR}\left(\mathrm{CDCl}_{3}, 50{ }^{\circ} \mathrm{C}, 400 \mathrm{MHz}\right) \delta(\mathrm{ppm}): 5.80$ (m, 2H), $4.94(\mathrm{~m}, 4 \mathrm{H}), 3.27(\mathrm{~m}, 4 \mathrm{H}), 3.19(\mathrm{~m}, 4 \mathrm{H}), 2.27(\mathrm{t}, 4 \mathrm{H}), 2.02(\mathrm{~m}, 4 \mathrm{H}), 1.62(\mathrm{~m}, 4 \mathrm{H}), 1.51$ (m, 8H), 1.36-1.28 (m, 40H), 0.88 (m, 6H). IR $\left(\mathrm{cm}^{-1}\right): 2924,2851,1642,906$.

\section{2- Epoxidation reaction}

The diester or diamide and m-CPBA ( 3 eq. and 4.5 eq. for UndBdA) were stirred at room temperature in DCM (20mL/g of product) or chloroform (for UndBdA). After 1 day, the conversion of the double bonds, monitored by ${ }^{1} \mathrm{H}$ NMR spectroscopy, were in the range $84 \%$ to $100 \%$. The reaction mixture was then thoroughly washed with aqueous $\mathrm{Na}_{2} \mathrm{SO}_{3}(3 \times 50 \mathrm{~mL})$, aqueous $\mathrm{NaHCO}_{3}(4 \times 50 \mathrm{~mL})$ and water $(4 \times 50 \mathrm{~mL})$ until neutral $\mathrm{pH}$. The organic layer was dried over anhydrous sodium sulfate filtered and solvent was remove on rotary evaporator to obtain the bis epoxides.

UndPdE-bisEpoxide: UndPdE (17 g, $42 \mathrm{mmol})$ and m-CPBA (21.5 g, $125 \mathrm{mmol}, 3$ eq.). The purity of UndPdE-bisEpoxide (92.8\%) was determined by GC-FID. Yield $=95.9 \% .{ }^{1} \mathrm{H}$ NMR $\left(\mathrm{CDCl}_{3}, 25^{\circ} \mathrm{C}, 400\right.$ MHz) $\delta(\mathrm{ppm}): 4.12(\mathrm{t}, 4 \mathrm{H}), 2.90(\mathrm{~m}, 2 \mathrm{H}), 2.74(\mathrm{t}, 2 \mathrm{H}), 2.45(\mathrm{~m}, 2 \mathrm{H}), 2.29(\mathrm{t}, 4 \mathrm{H}), 1.95(\mathrm{~m}, 2 \mathrm{H}), 1.61$ (m, 4H), 1.51 (m, 4H), $1.44(\mathrm{~m}, 4 \mathrm{H}), 1.30$ (m, 16H). IR (cm-1): 2927, 2856, 1732, 1161.

UndBdA-bisEpoxide: UndBdA (12.7 g, $30 \mathrm{mmol})$ and m-CPBA (23.4 g, $136 \mathrm{mmol}, 4.5$ eq.). The purity of UndBdA-bisEpoxide (80.4\%) was determined by GC-FID. Yield=97\%. ${ }^{1} \mathrm{H}$ NMR $\left(\mathrm{CDCl}_{3}\right.$, $\left.25^{\circ} \mathrm{C}, 400 \mathrm{MHz}\right) \delta(\mathrm{ppm}): 5.79(\mathrm{~s}, 2 . \mathrm{NH}), 3.26(\mathrm{~m}, 4 \mathrm{H}), 2.89(\mathrm{~m}, 2 \mathrm{H}), 2.74(\mathrm{t}, 2 \mathrm{H}), 2.46(\mathrm{~m}, 2 \mathrm{H}), 2.16$ $(\mathrm{t}, 4 \mathrm{H}), 1.71(\mathrm{~m}, 4 \mathrm{H}), 1.61-1.53(\mathrm{~m}, 12 \mathrm{H}), 1.31(\mathrm{~m}, 16 \mathrm{H}) . \mathrm{IR}\left(\mathrm{cm}^{-1}\right): 3292,2912,2851,1631,1537$.

UndPipdA-bisEpoxide: UndPipdA (13.2 g, $31 \mathrm{mmol})$ and m-CPBA (16.3 g, $95 \mathrm{mmol}, 3$ eq.). The purity of UndPipdA-bisEpoxide $(97.9 \%)$ was determined by GC-FID. Yield=84.5\%. ${ }^{1} \mathrm{H}$ NMR $\left(\mathrm{CDCl}_{3}\right.$, $\left.25{ }^{\circ} \mathrm{C}, 400 \mathrm{MHz}\right) \delta(\mathrm{ppm}): 3.61(\mathrm{~m}, 4 \mathrm{H}), 3.45(\mathrm{~m}, 4 \mathrm{H}), 2.88(\mathrm{~m}, 2 \mathrm{H}), 2.73(\mathrm{t}, 2 \mathrm{H}), 2.45(\mathrm{~m}, 2 \mathrm{H}), 2.32$ $(\mathrm{t}, 4 \mathrm{H}), 1.61(\mathrm{~m}, 4 \mathrm{H}), 1.49-1.44(\mathrm{~m}, 8 \mathrm{H}), 1.34-1.30$ (m, 16H). IR $\left(\mathrm{cm}^{-1}\right): 2913,2848,1651$.

UndPMedA-bisEpoxide: UndPMedA (20 g, $46 \mathrm{mmol})$ and m-CPBA (23.8 g, $138 \mathrm{mmol}, 3$ eq.). The purity of UndPMedA-bisEpoxide $(93.9 \%)$ was determined by GC-FID. Yield=83.9\%. ${ }^{1} \mathrm{H}$ NMR 
$\left(\mathrm{CDCl}_{3}, 25{ }^{\circ} \mathrm{C}, 400 \mathrm{MHz}\right) \delta(\mathrm{ppm}): 3.37(\mathrm{~m}, 4 \mathrm{H}), 3.00-2.92(\mathrm{~s}, 6 \mathrm{H}), 2.90(\mathrm{~m}, 2 \mathrm{H}), 2.75(\mathrm{t}, 2 \mathrm{H}), 2.46$ (m, 2H), $2.31(\mathrm{~m}, 4 \mathrm{H}), 1.79(\mathrm{~m}, 2 \mathrm{H}), 1.61(\mathrm{~m}, 4 \mathrm{H}), 1.51(\mathrm{~m}, 4 \mathrm{H}), 1.42(\mathrm{~m}, 4 \mathrm{H}), 1.29(\mathrm{~m}, 16 \mathrm{H}) . \mathrm{IR}^{\left(\mathrm{cm}^{-}\right.}$ 1): 2924, 2854, 1639 .

UndDHexdA-bisEpoxide: UndDHexdA (10 g, $15 \mathrm{mmol})$ and m-CPBA (7.7 g, $44 \mathrm{mmol}, 3$ eq.). Yield $=54.4 \%$. ${ }^{1} \mathrm{H}$ NMR $\left(\mathrm{CDCl}_{3}, 25^{\circ} \mathrm{C}, 400 \mathrm{MHz}\right) \delta(\mathrm{ppm}): 3.28(\mathrm{~m}, 4 \mathrm{H}), 3.19(\mathrm{~m}, 4 \mathrm{H}), 2.89(\mathrm{~m}, 2 \mathrm{H})$, $2.73(\mathrm{t}, 2 \mathrm{H}), 2.46(\mathrm{~m}, 2 \mathrm{H}), 2.27(\mathrm{t}, 4 \mathrm{H}), 1.62(\mathrm{~m}, 4 \mathrm{H}), 1.43(\mathrm{~m}, 16 \mathrm{H}), 1.31(\mathrm{~m}, 40 \mathrm{H}), 0.88$ (m, 6H). IR $\left(\mathrm{cm}^{-1}\right): 2924,2853,1637$.

\section{3-Synthesis of 5-membered cyclic carbonates}

The bis-epoxide was first pre-mixed with $\mathrm{TBABr}(3 \mathrm{wt} \%)$. Then the mixture was placed in a reactor and heated up at the selected temperature $\left(80^{\circ} \mathrm{C}\right.$ for UndPdE-bisEpoxide, UndPMedA-bisEpoxide and UndDHexdA-bisEpoxide, $135^{\circ} \mathrm{C}$ for UndPipdA-bisEpoxide and $140^{\circ} \mathrm{C}$ for UndBdA-bisEpoxide). Once the temperature got stabilized, $\mathrm{CO}_{2}$ was slowly introduced into the reactor until 50 Bar or $60 \mathrm{Bar}$ in the case of UndBdA-bisEpoxide. After 24 hours, the reactor was cooled down to room temperature and slowly depressurized to the atmospheric pressure. All the ${ }^{1} \mathrm{H}$ NMR of all products revealed quantitative conversion by the disappearance of the protons of the epoxide.

UndPdE-CC: UndPdE-bisEpoxide ( $3 \mathrm{~g}, 6.8 \mathrm{mmol})$ and TBABr (0.09 g, $0.28 \mathrm{mmol}, 3 \mathrm{wt} \%)$. The purity of UndPdE-bisEpoxide (99.1\%) was determined by SEC. Yield $=97 \%$. ${ }^{1} \mathrm{H} \mathrm{NMR}\left(\mathrm{CDCl}_{3}, 25^{\circ} \mathrm{C}\right.$, $400 \mathrm{MHz}) \delta(\mathrm{ppm}): 4.68(\mathrm{~m}, 2 \mathrm{H}), 4.50(\mathrm{t}, 2 \mathrm{H}), 4.11(\mathrm{t}, 4 \mathrm{H}), 4.04(\mathrm{t}, 2 \mathrm{H}), 2.27(\mathrm{t}, 4 \mathrm{H}), 1.94(\mathrm{~m}, 2 \mathrm{H})$, $1.76(\mathrm{~m}, 2 \mathrm{H}), 1.66(\mathrm{~m}, 2 \mathrm{H}), 1.58(\mathrm{~m}, 4 \mathrm{H}), 1.45(\mathrm{~m}, 4 \mathrm{H}), 1.28(\mathrm{~m}, 16 \mathrm{H}),{ }^{13} \mathrm{C} \mathrm{NMR}\left(\mathrm{CDCl}_{3}, 25^{\circ} \mathrm{C}, 100\right.$ MHz) $\delta$ (ppm): 173.81 (COO), 155.20 (OCOO), 77.21 ( $\underline{\mathrm{CH}}-\mathrm{OCOO}), 69.51$ ( $\left.\underline{\mathrm{CH}}_{2}-\mathrm{OCOO}\right), 60.93$ ( $\left.\underline{\mathrm{CH}}_{2}-\mathrm{OCO}\right), 34.28$ ( $\left.\underline{\mathrm{CH}}_{2}-\mathrm{COO}\right), 33.95$ ( $\left.\underline{\mathrm{CH}}_{2}-\mathrm{CH}-\mathrm{OCOO}\right), 29.21-29.13\left(\mathrm{CH}_{2}\right), 28.10\left(\underline{\mathrm{CH}}_{2}-\mathrm{CH}_{2}-\mathrm{OCO}\right)$, $24.94\left(\underline{\mathrm{CH}}_{2}-\mathrm{CH}_{2}-\mathrm{COO}\right), 24.44\left(\underline{\mathrm{CH}}_{2}-\mathrm{CH}_{2}-\mathrm{CH}-\mathrm{OCOO}\right)$.

UndBdA-b5CC: UndBdA-bisEpoxide (3 g, $6.6 \mathrm{mmol})$ and TBABr $(0.09 \mathrm{~g}, 0.28 \mathrm{mmol}, 4.5 \mathrm{wt} \%)$. Yield $=95 \%$. ${ }^{1} \mathrm{H} \mathrm{NMR}\left(\mathrm{CDCl}_{3}, 25^{\circ} \mathrm{C}, 400 \mathrm{MHz}\right) \delta(\mathrm{ppm}): 5.83$ (s, 2.NH), $4.70(\mathrm{~m}, 2 \mathrm{H}), 4.53(\mathrm{t}, 2 \mathrm{H})$, $4.06(\mathrm{t}, 2 \mathrm{H}), 3.26(\mathrm{~m}, 4 \mathrm{H}), 2.16(\mathrm{t}, 4 \mathrm{H}), 1.78(\mathrm{~m}, 2 \mathrm{H}), 1.62(\mathrm{~m}, 6 \mathrm{H}), 1.53(\mathrm{~m}, 4 \mathrm{H}), 1.47(\mathrm{~m}, 4 \mathrm{H}), 1.30$ (m, 16H). ${ }^{13} \mathrm{C} \mathrm{NMR}\left(\mathrm{CDCl}_{3}, 25^{\circ} \mathrm{C}, 100 \mathrm{MHz}\right) \delta(\mathrm{ppm}): 173.81(\mathrm{CONH}), 155.27$ (OCOO), 77.22 (다OCOO), 69.54 ( $\left.\underline{\mathrm{CH}}_{2}-\mathrm{OCOO}\right), 39.20$ ( $\left.\underline{\mathrm{C}}_{2}-\mathrm{NHCO}\right), 36.65\left(\underline{\mathrm{CH}}_{2}-\mathrm{CONH}\right), 33.94\left(\underline{\mathrm{CH}}_{2}-\mathrm{CH}-\mathrm{OCOO}\right)$, $29.17\left(\mathrm{CH}_{2}\right), 26.91\left(\mathrm{CH}_{2}-\mathrm{CH}_{2}-\mathrm{NHCO}\right), 25.84\left(\underline{\mathrm{CH}}_{2}-\mathrm{CH}_{2}-\mathrm{CONH}\right), 24.43\left(\underline{\mathrm{CH}}_{2}-\mathrm{CH}_{2}-\mathrm{CH}-\mathrm{OCOO}\right)$. $\left(\mathrm{cm}^{-1}\right): 3309,2918,2850,1778,1637,1535$.

UndPipdA-b5CC: UndPipdA-bisEpoxide (5 g, $11.1 \mathrm{mmol})$ and TBABr $(0.15 \mathrm{~g}, 0.46 \mathrm{mmol}, 3 \mathrm{wt} \%)$. Yield=98\%. ${ }^{1} \mathrm{H}$ NMR $\left(\mathrm{CDCl}_{3}, 25{ }^{\circ} \mathrm{C}, 400 \mathrm{MHz}\right) \delta(\mathrm{ppm}): 4.69(\mathrm{~m}, 2 \mathrm{H}), 4.51(\mathrm{t}, 2 \mathrm{H}), 4.06(\mathrm{t}, 2 \mathrm{H}), 3.62$ (m, 4H), $3.45(\mathrm{~m}, 4 \mathrm{H}), 2.32(\mathrm{t}, 4 \mathrm{H}), 1.76(\mathrm{~m}, 2 \mathrm{H}), 1.70-1.63(\mathrm{~m}, 8 \mathrm{H}), 1.47(\mathrm{~m}, 2 \mathrm{H}), 1.31(\mathrm{~m}, 16 \mathrm{H})$. ${ }^{13} \mathrm{C} \mathrm{NMR}\left(\mathrm{CDCl}_{3}, 25^{\circ} \mathrm{C}, 100 \mathrm{MHz}\right) \delta(\mathrm{ppm}): 172.00(\mathrm{C}=\mathrm{O}-\mathrm{N}), 155.15$ (OCOO), 77.12 (ㄷH-OCOO), $69.47\left(\underline{\mathrm{C}} \mathrm{H}_{2}-\mathrm{OCOO}\right), 45.41$ and $41.61\left(\left(\underline{\mathrm{C}} \mathrm{H}_{2}\right)_{2}-\mathrm{N}-\mathrm{C}=\mathrm{O}\right), 33.93\left(\underline{\mathrm{CH}}_{2}-\mathrm{CH}-\mathrm{OCOO}\right), 33.29\left(\underline{\mathrm{C}}_{2}-\mathrm{C}=\mathrm{O}-\mathrm{N}\right)$, $29.25\left(\mathrm{CH}_{2}\right), 25.20\left(\underline{\mathrm{CH}}_{2}-\mathrm{CH}_{2}-\mathrm{C}=\mathrm{O}-\mathrm{N}\right), 24.42\left(\underline{\mathrm{CH}}_{2}-\mathrm{CH}_{2}-\mathrm{CH}-\mathrm{OCOO}\right) . \mathrm{IR}\left(\mathrm{cm}^{-1}\right): 2915,2847,1775$, 1628. 
UndPMedA-b5CC: UndPMedA-bisEpoxide (5 g, $10.7 \mathrm{mmol})$ and $\mathrm{TBABr}(0.15 \mathrm{~g}, 0.46 \mathrm{mmol}$, $3 \mathrm{wt} \%)$. The purity of UndPMedA-bisEpoxide $(88.6 \%)$ was determined by GC-FID. Yield $=96 \%$. ${ }^{1} \mathrm{H}$ $\operatorname{NMR}\left(\mathrm{CDCl}_{3}, 25^{\circ} \mathrm{C}, 400 \mathrm{MHz}\right) \delta(\mathrm{ppm}): 4.69(\mathrm{~m}, 2 \mathrm{H}), 4.51(\mathrm{t}, 2 \mathrm{H}), 4.05(\mathrm{t}, 2 \mathrm{H}), 3.34-3.27(\mathrm{~m}, 4 \mathrm{H})$, 2.98-2.89 (s, 6H), $2.27(\mathrm{~m}, 4 \mathrm{H}), 1.79(\mathrm{~m}, 6 \mathrm{H}), 1.61(\mathrm{~m}, 6 \mathrm{H}), 1.47(\mathrm{~m}, 2 \mathrm{H}), 1.30(\mathrm{~m}, 16 \mathrm{H}) .{ }^{13} \mathrm{C}$ NMR $\left(\mathrm{CDCl}_{3}, 25^{\circ} \mathrm{C}, 100 \mathrm{MHz}\right) \delta(\mathrm{ppm}): 173.12\left(\underline{\mathrm{CONCH}}_{3}\right), 155.20$ (OCOO), 77.16 (ㅁH-OCOO), 69.51 ( $\left.\underline{\mathrm{CH}}_{2}-\mathrm{OCOO}\right), 47.76-45.50$ ( $\left.\underline{\mathrm{CH}}_{2}-\mathrm{NCH}_{3} \mathrm{CO}\right), 35.51-33.08$ ( $\left.\mathrm{NCH}_{3} \mathrm{CO}\right), 33.92$ ( $\left.\underline{\mathrm{CH}}_{2}-\mathrm{CH}-\mathrm{OCOO}\right), 33.65-$ $33.38\left(\underline{\mathrm{CH}}_{2}-\mathrm{CONCH}_{3}\right), 29.52-24.46\left(\mathrm{CH}_{2}\right), 26.53\left(\underline{\mathrm{CH}}_{2}-\mathrm{CH}_{2}-\mathrm{NCH}_{3} \mathrm{CO}\right) . \mathrm{IR}\left(\mathrm{cm}^{-1}\right): 2913,2847,1787$, 1631.

UndDHexdA-b5CC: UndDHexdA-bisEpoxide (3 g, $4.2 \mathrm{mmol})$ and $\mathrm{TBABr}(0.09 \mathrm{~g}, 0.28 \mathrm{mmol}, 3$ wt\%). Yield $=88.7 \% .{ }^{1} \mathrm{H}$ NMR $\left(\mathrm{CDCl}_{3}, 25{ }^{\circ} \mathrm{C}, 400 \mathrm{MHz}\right) \delta(\mathrm{ppm}): 4.67(\mathrm{~m}, 2 \mathrm{H}), 4.50(\mathrm{t}, 2 \mathrm{H}), 4.04(\mathrm{t}$, $2 \mathrm{H}), 3.25(\mathrm{~m}, 4 \mathrm{H}), 3.17(\mathrm{~m}, 4 \mathrm{H}), 2.24(\mathrm{t}, 4 \mathrm{H}), 1.75(\mathrm{~m}, 2 \mathrm{H}), 1.65-1.60(\mathrm{~m}, 6 \mathrm{H}), 1.45(\mathrm{~m}, 12 \mathrm{H}), 1.29$ $(\mathrm{m}, 40 \mathrm{H}), 0.87(\mathrm{~m}, 6 \mathrm{H}) \cdot{ }^{13} \mathrm{C} \mathrm{NMR}\left(\mathrm{CDCl}_{3}, 25^{\circ} \mathrm{C}, 100 \mathrm{MHz}\right) \delta(\mathrm{ppm}): 173.10\left(\mathrm{CONCH}_{3}\right), 155.14$ (OCOO), 76.97 ( $\underline{\mathrm{CH}}-\mathrm{OCOO}), 69.27$ ( $\left.\underline{\mathrm{CH}}_{2}-\mathrm{OCOO}\right), 47.73-45.56\left(\underline{\mathrm{CH}}_{2}-\mathrm{NCO}\right), 33.59$ ( $\left.\underline{\mathrm{CH}}_{2}-\mathrm{CH}-\mathrm{OCOO}\right)$,

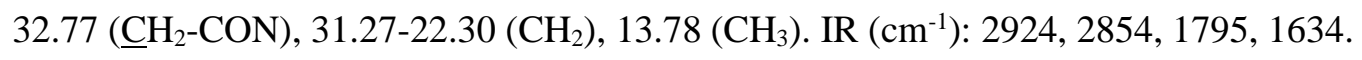

\section{Polymer synthesis and characterizations}

The bis 5-membered cyclic carbonates (UndPdE-b5CC, UndBdA-b5CC, UndPipdA-b5CC, UndPMedA-b5CC and UndDHexdA-CC) and the diamines (butane-1,4-diamine (4DA), isophorone diamine (IPDA), Jeffamine 400 g.mol ${ }^{-1}$, CRODA diamine) were weighted in a test tube. The polymerization reactions were conducted in bulk under static nitrogen. The mixture was stirred at the selected temperature: $140^{\circ} \mathrm{C}$ (for UndBdA-b5CC and UndPipdA-b5CC), $120^{\circ} \mathrm{C}$ (for UndPMedAb5CC and UndDHexdA-b5CC) and $70^{\circ} \mathrm{C}$ or $110^{\circ} \mathrm{C} / 120^{\circ} \mathrm{C}$ for UndPdE-b5CC. No catalysts were added for the polymerization reactions.

PHU-dE-1 [UndPdE-b5CC+4DA] : 3655-3127, 2924, 2854, 1714-1691, 1528.

PHU-BdA-1 [UndBdA-b5CC+IPDA] : 3536-3132, 2922, 2852, 1700, 1642, 1539.

PHU-DHexdA-1 [UndDHexdA-b5CC+IPDA] : 3595-3128, 2922, 2852, 1713, 1626, 1535.

\section{Kinetic experiments monitored by FTIR-ATR of the cyclic carbonate- amine reaction}

The kinetic experiments were performed in bulk at $25^{\circ} \mathrm{C}$ with a ratio $1: 1$ between the propylene carbonate and hexylamine, using $5 \mathrm{~mol} \%$ of catalyst. For some experiments, higher temperature $\left(80^{\circ} \mathrm{C}\right)$ was also investigated. For instance; propylene carbonate $(5 \mathrm{CC})(0.25 \mathrm{~g}, 2.4 \mathrm{mmol})$ and MTBD (18.7 mg, $0.12 \mathrm{mmol}, 5 \mathrm{~mol} \%)$ were weighted in a test tube. Then, hexylamine $(0.25 \mathrm{~g}, 2.4 \mathrm{mmol})$ was added to the reaction mixture. The reaction was monitored with FTIR-ATR spectroscopy with the disappearance of the carbonyl band of the cyclic carbonate. Two isomers are obtained; one with a primary alcohol (isomer $\mathrm{OH}-\mathrm{I}$ ) and one with a secondary alcohol (isomer $\mathrm{OH}-\mathrm{II}$ ). 
PCC+hexylamine-isomer $\boldsymbol{O H}-\boldsymbol{I I}:{ }^{1} \mathrm{H}$ NMR $\left(\mathrm{CDCl}_{3}, 25^{\circ} \mathrm{C}, 400 \mathrm{MHz}\right) \delta(\mathrm{ppm}): 4.97(\mathrm{NH}), 4.05$ (m, 1H), $3.98(\mathrm{~m}, 1 \mathrm{H}), 3.91(\mathrm{~m}, 1 \mathrm{H}), 3.14(\mathrm{~m}, 2 \mathrm{H}), 1.47(\mathrm{~m}, 2 \mathrm{H}), 1.27(\mathrm{~m}, 6 \mathrm{H}), 1.15(\mathrm{~d}, 3 \mathrm{H}), 0.86(\mathrm{t}$, $3 \mathrm{H}) .{ }^{13} \mathrm{C} \mathrm{NMR}\left(\mathrm{CDCl}_{3}, 25^{\circ} \mathrm{C}, 100 \mathrm{MHz}\right) \delta(\mathrm{ppm}): 156.98$ (OCONH), 72.69 ( $\left.\underline{\mathrm{C}} \mathrm{H}-\mathrm{OCONH}\right), 66.52$ $\left(\underline{\mathrm{C}} \mathrm{H}_{2}-\mathrm{OH}\right), 41.17\left(\underline{\mathrm{CH}}_{2}-\mathrm{NHCOO}\right), 29.94\left(\underline{\mathrm{CH}}_{2}-\mathrm{CH}_{2}-\mathrm{NHCOO}\right), 31.54-22.64\left(\mathrm{CH}_{2}\right), 16.70\left(\underline{\mathrm{CH}}_{3}-\mathrm{CH}-\right.$ OCONH), $14.08\left(\mathrm{CH}_{2}-\underline{\mathrm{CH}}_{3}\right)$. IR ( $\left.\mathrm{cm}^{-1}\right)$ : 3321, 2929, 2856, 1687, 1533.

PCC+hexylamine-isomer $\boldsymbol{O H}-\mathrm{I}:{ }^{1} \mathrm{H}$ NMR $\left(\mathrm{CDCl}_{3}, 25^{\circ} \mathrm{C}, 400 \mathrm{MHz}\right) \delta(\mathrm{ppm}): 4.97(\mathrm{NH}), 4.85$ (m, 1H), 3.63-3.55 (m, 2H), $3.14(\mathrm{~m}, 2 \mathrm{H}), 1.47(\mathrm{~m}, 2 \mathrm{H}), 1.27(\mathrm{~m}, 6 \mathrm{H}), 1.17(\mathrm{~d}, 3 \mathrm{H}), 0.86(\mathrm{t}, 3 \mathrm{H}) .{ }^{13} \mathrm{C}$ $\mathrm{NMR}\left(\mathrm{CDCl}_{3}, 25^{\circ} \mathrm{C}, 100 \mathrm{MHz}\right) \delta(\mathrm{ppm}): 156.98(\mathrm{OCONH}), 70.21\left(\underline{\mathrm{CH}}_{2}-\mathrm{OCONH}\right), 66.61(\underline{\mathrm{CH}}-\mathrm{OH})$, $41.17\left(\underline{\mathrm{CH}}_{2}-\mathrm{NHCOO}\right), 29.94\left(\underline{\mathrm{CH}}_{2}-\mathrm{CH}_{2}-\mathrm{NHCOO}\right), 31.54-22.64\left(\mathrm{CH}_{2}\right), 19.17\left(\underline{\mathrm{CH}}_{3}-\mathrm{CH}-\mathrm{OH}\right), 14.08$ $\left(\mathrm{CH}_{2}-\mathrm{CH}_{3}\right)$. IR $\left(\mathrm{cm}^{-1}\right): 3321,2929,2856,1687,1533$.

\section{Conclusions}

Various fatty acid-based 5-membered cyclic carbonate dimers bearing ester or amide linkages have been synthesized following a three-step procedure. The first stage was the transesterification or the amidation of methyl undecenoate. Then, the cyclic carbonates were introduced by epoxidation of the double bonds and subsequent carbonation with $\mathrm{CO}_{2}$. Amorphous to semi-crystalline poly(hydroxyurethane)s with reasonable molar masses (31000 g. $\left.\mathrm{mol}^{-1}\right)$ have been achieved. The tailor-made bio-based thermoplastic poly(hydroxyurethane)s properties are those expected when using cyclic carbonate dimers and diamines structures. Indeed, the presence of ester or amide functions, of hydrogen bonds through amide linkages and of cyclic structures or pendant groups or alkyl chains were found to drastically modify the PHUs properties.

\section{Acknowledgement}

The authors thank University of Bordeaux, ANR (Polygreen, $\left.\mathrm{N}^{\circ}------\right)$, IPB, CNRS and Aquitaine Council for the financial support of this research. Authors also acknowledge Anne-Laure Wirotius for her help during variable temperature NMR studies.

\section{References}

1. L. Maisonneuve, T. Lebarbe, E. Grau and H. Cramail, Polymer Chemistry, 2013, 4, 5472-5517.

2. M. Desroches, M. Escouvois, R. Auvergne, S. Caillol and B. Boutevin, Polymer Reviews, 2012, 52, 38-79.

3. D. P. Pfister, Y. Xia and R. C. Larock, ChemSusChem, 2011, 4, 703-717.

4. G. Lligadas, J. C. Ronda, M. Galià and V. Cádiz, Biomacromolecules, 2010, 11, 2825 2835.

5. B. Nohra, L. Candy, J.-F. Blanco, C. Guerin, Y. Raoul and Z. Mouloungui, Macromolecules, 2013, 46, 3771-3792.

6. O. Kreye, H. Mutlu and M. A. R. Meier, Green Chemistry, 2013, 15, 1431-1455. 
7. M. S. Kathalewar, P. B. Joshi, A. S. Sabnis and V. C. Malshe, RSC Advances, 2013, 3, 4110-4129.

8. J. Guan, Y. Song, Y. Lin, X. Yin, M. Zuo, Y. Zhao, X. Tao and Q. Zheng, Industrial \& Engineering Chemistry Research, 2011, 50, 6517-6527.

9. B. Lebedev, V. Veridusova, H. Höcker and H. Keul, Macromolecular Chemistry and Physics, 2002, 203, 1114-1125.

10. J. Kušan, H. Keul and H. Höcker, Macromolecules, 2001, 34, 389-395.

11. S. Neffgen, J. Kušan, T. Fey, H. Keul and H. Höcker, Macromolecular Chemistry and Physics, 2000, 201, 2108-2114.

12. P. Deepa and M. Jayakannan, Journal of Polymer Science, Part A: Polymer Chemistry, 2008, 46, 2445-2458.

13. B. Ochiai and T. Utsuno, Journal of Polymer Science Part A: Polymer Chemistry, 2012, 51, 525-533.

14. E. Hablot, D. Graiver and R. Narayan, in PU Magazine International, 2012, pp. 255257.

15. M. Unverferth, O. Kreye, A. Prohammer and M. A. R. Meier, Macromolecular Rapid Communications, 2013, 34, 1569-1574.

16. D. V. Palaskar, A. Boyer, E. Cloutet, C. Alfos and H. Cramail, Biomacromolecules, 2010, 11, 1202-1211.

17. A. S. More, B. Gadenne, C. Alfos and H. Cramail, Polymer Chemistry, 2012, 3, 15941605.

18. A. Boyer, E. Cloutet, T. Tassaing, B. Gadenne, C. Alfos and H. Cramail, Green Chemistry, 2010, 12, 2205-2213.

19. M. Bahr and R. Mulhaupt, Green Chemistry, 2012, 14, 483-489.

20. I. Javni, D. P. Hong and Z. S. Petrović, Journal of Applied Polymer Science, 2012, 128, 566-571.

21. I. Javni, P. H. Doo and Z. S. Petrovic, Journal of Applied Polymer Science, 2008, 108, 3867-3875.

22. S. Foltran, J. Alsarraf, F. Robert, Y. Landais, E. Cloutet, H. Cramail and T. Tassaing, Catalysis Science \& Technology, 2013, 3, 1046-1055.

23. S. Foltran, L. Maisonneuve, E. Cloutet, B. Gadenne, C. Alfos, T. Tassaing and H. Cramail, Polymer Chemistry, 2012, 3, 525-532.

24. S. Foltran, R. Mereau and T. Tassaing, Physical Chemistry Chemical Physics, 2011, 13, 9209-9215.

25. H. Tomita, F. Sanda and T. Endo, Journal of Polymer Science Part A: Polymer Chemistry, 2001, 39, 3678-3685.

26. R. M. Garipov, V. A. Sysoev, V. V. Mikheev, A. I. Zagidullin, R. Y. Deberdeev, V. I. Irzhak and A. A. Berlin, Doklady Physical Chemistry, 2003, 393, 289-292. 


\section{TOC}

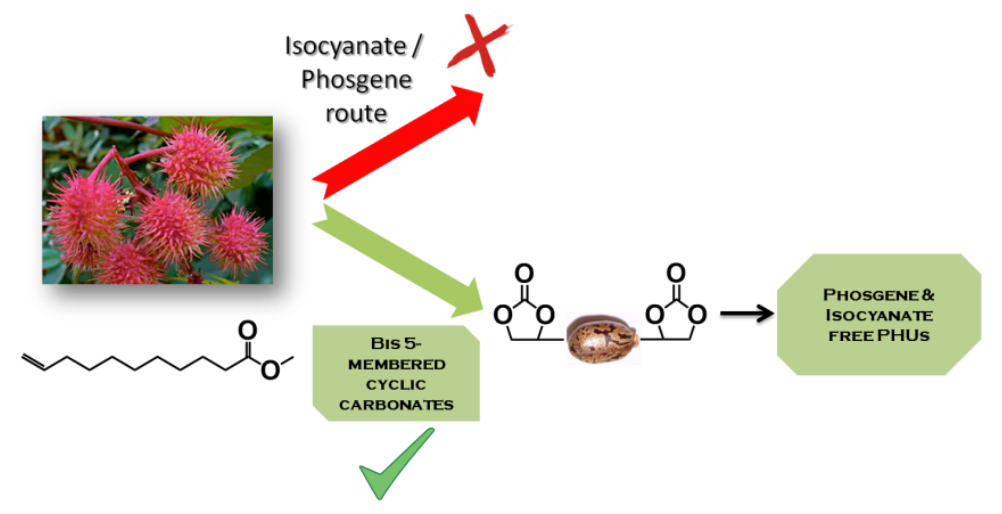




\title{
SUPPLEMENTARY INFORMATION Novel green fatty acid based-bis cyclic carbonates to isocyanate free poly(hydroxyurethane amide)s
}

\author{
Lise Maisonneuve ${ }^{\mathrm{a}, \mathrm{b}}$, Arvind S. More ${ }^{\mathrm{a}, \mathrm{b}}$, Stéphanie Foltran ${ }^{\mathrm{c}, \mathrm{d}}$, Carine Alfos ${ }^{\mathrm{e}}$, Fréderic Robert ${ }^{\mathrm{c}, \mathrm{d}}$, \\ Yannick Landais $^{\mathrm{c}, \mathrm{d}}$, Thierry Tassaing ${ }^{\mathrm{c}, \mathrm{d}}$, Etienne Grau ${ }^{\mathrm{a}, \mathrm{b}}$, Henri Cramail ${ }^{\mathrm{a}, \mathrm{b} *}$ \\ ${ }^{a}$ Centre National de la Recherche Scientifique, Laboratoire de Chimie des Polymères Organiques, UMR 5629, \\ IPB/ENSCBP, 16 avenue Pey-Berland, F-33607 Pessac Cedex, France, E-mail: cramail@enscbp.fr \\ ${ }^{b}$ Univ. of Bordeaux, Laboratoire de Chimie des Polymères Organiques, UMR 5629, IPB/ENSCBP, 16 avenue \\ Pey-Berland, F-33607 Pessac Cedex, France \\ ${ }^{c}$ Centre National de la Recherche Scientifique, Institut des Sciences Moléculaires, UMR 5255, 351, Cours de la \\ libération, 33405 Talence Cedex, France. \\ ${ }^{d}$ Univ. of Bordeaux, Institut des Sciences Moléculaires, UMR 5255, 351, Cours de la libération, 33405 Talence \\ Cedex,France \\ e ITERG, 11 rue Gaspard Monge, F-33600 Pessac Cedex, France
}




\section{Supplemental Information Contents}

1-Materials

2- Measurments

3- Graphical data page 1

page 1

page 4

\section{1- Materials}

Methyl 10-undecenoate (>96.0\%), butane-1,4-diamine (4DA, 99\%) and 1,3-bis[3,5bis(trifluoromethyl)phenyl]thiourea (Schreiner catalyst, >98\%) were supplied by TCI, Europe. The 1,5,7-triazabicyclo[4.4.0]dec-5-ene (TBD, 98\%), 3-chloroperbenzoic acid ( $\leq 77 \%)$, tetrabutylammonium bromide ( $\mathrm{TBABr},>98 \%)$ and poly(propylene glycol) bis(2-aminopropyl ether) (Jeffamine, $\bar{M}_{\mathrm{n}}=400$ g.mol${ }^{-1}$ ) were obtained from Sigma-Aldrich. The 1,3-propanediol (99\%), dimethyl, piperazine (Pip, anhydrous, 99\%), N,N'-dimethylpropane-1,3-diamine (PMe, 97\%), sebacoyl chloride (97\%) and 1,4-butanediol (99\%) were purchased from Alfa Aesar. Isophorone diamine (IPDA, >99\%) was obtained from Fisher. The dimer fatty acid-based diamine (Priamine 1075) was purchased from CRODA. The catalyst 1-methyl-3-methylimidazolium iodide salt (MMII) was purchased from Solvionic and the 1,5,7-triaza-bicyclo[4.4.0]dec-5-enium bromide (TBD.HBr) was synthesized by our partners from the research group of Landais and coll. (S. Foltran, J. Alsarraf, F. Robert, Y. Landais, E. Cloutet, H. Cramail and T. Tassaing, Catalysis Science \& Technology, 2013, 3, 1046-1055.) All products and solvents (reagent grade) were used as received except otherwise mentioned. The solvents were of reagent grade quality and were purified wherever necessary according to the methods reported in the literature.

\section{2- Measurements}

\section{1- Nuclear Magnetic Resonance (NMR) analysis}

${ }^{1} \mathrm{H}$ and ${ }^{13} \mathrm{C}$-NMR spectra were recorded on Bruker Avance 400 spectrometer $(400.20 \mathrm{MHz}$ or 400.33 $\mathrm{MHz}$ and $100.63 \mathrm{MHz}$ for ${ }^{1} \mathrm{H}$ and ${ }^{13} \mathrm{C}$, respectively) by using $\mathrm{CDCl}_{3}$ as a solvent at room temperature, except otherwise mentionned. Two-dimensional analyses such as ${ }^{1} \mathrm{H}-{ }^{1} \mathrm{H}$ COSY (Homonuclear correlation Spectroscopy) and ${ }^{1} \mathrm{H}^{-13} \mathrm{C}$ HSQC (Heteronuclear single quantum coherence) were also performed on the monomers.

\section{2- Fourier Transformed Infra-Red-Attenuated Total Reflection (FTIR-ATR)}

Infrared spectra (FTIR-ATR) were obtained on a Bruker-Tensor 27 spectrometer, equipped with a diamond crystal, using the attenuated total reflection mode. The spectra were acquired using 16 scans at a resolution of 4 wavenumbers. 


\section{3- Kinetic experiments monitored by in-situ FTIR of the carbonation reaction (ISM)}
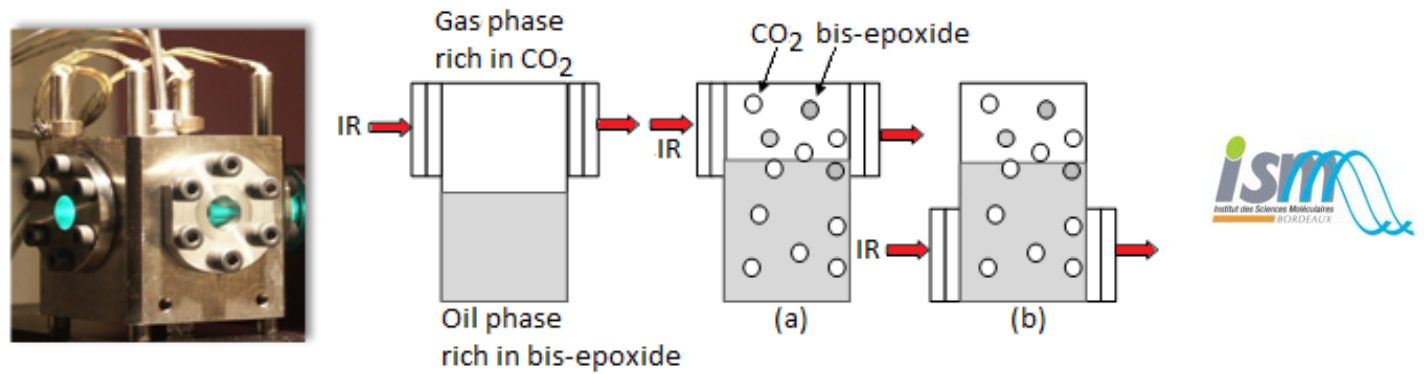

The in situ infrared absorption measurements were performed at the Institut des Sciences moléculaires (ISM) on a Biorad interferometer (type FTS-60A) equipped with a globar as the infrared source, a $\mathrm{KBr} / \mathrm{Ge}$ beam splitter and a DTGS (deuterated triglycine sulfate) detector in order to investigate the spectral range 400-6000 $\mathrm{cm}^{-1}$. Single beam spectra recorded with a $2 \mathrm{~cm}^{-1}$ resolution were obtained after the Fourier transformation of 50 accumulated interferograms. The kinetic studies of the carbonation reaction were performed using the ISM home-made stainless steel cell equipped with two cylindrical germanium windows with a path length of $100 \mu \mathrm{m}$ in order to measure the infrared spectra in the wavenumber range extending from 700 to $5000 \mathrm{~cm}^{-1}$. Heating was achieved by using four cartridge heaters distributed throughout the body of the cell. Two thermocouples were used, the first one located close to a cartridge heater for the temperature regulation and the second one close to the sample area to measure the temperature of the sample with an accuracy of about $2^{\circ} \mathrm{C}$. The cell was connected via a stainless steel capillary to a hydraulic pressurizing system which allows the pressure to be raised up to $50 \mathrm{MPa}$ with an absolute uncertainty of $\pm 0.1 \mathrm{MPa}$ and a relative error of $\pm 0.3 \%$.

\section{4- Size exclusion chromatography (SEC)}

SEC analyses of PUs were performed in DMF $\left(80^{\circ} \mathrm{C}\right)$ on a PL-GPC 50 plus Integrated GPC from Polymer laboratories-Varian with a series of three columns from Polymer Laboratories (PLgel: PLgel $5 \mu \mathrm{m}$ Guard (guard column $7.5 \mathrm{~mm}$ ID $\times 5.0 \mathrm{~cm} \mathrm{~L}$ ); PLgel $5 \mu \mathrm{m}$ MIXED-D $(7.5 \mathrm{~mm} \mathrm{ID} \mathrm{\times 30.0} \mathrm{cm} \mathrm{L)} \mathrm{and} \mathrm{PLgel}$ $5 \mu \mathrm{m}$ MIXED-D (7.5 mm ID x $30.0 \mathrm{~cm} \mathrm{~L}))$. The elution times of the filtered samples were monitored using RI detectors.

\section{5- Differential Scanning Calorimetry (DSC)}

Differential scanning calorimetry (DSC) thermograms were measured using a DSC Q100 apparatus from TA instruments. For each sample, two cycles from -50 to $160{ }^{\circ} \mathrm{C}$ (or $200{ }^{\circ} \mathrm{C}$ for higher melting point polyurethanes) at $10{ }^{\circ} \mathrm{C} \cdot \mathrm{min}^{-1}$ were performed and then the glass transition and crystallization temperatures were calculated from the second heating run. 


\section{3- Graphical data}

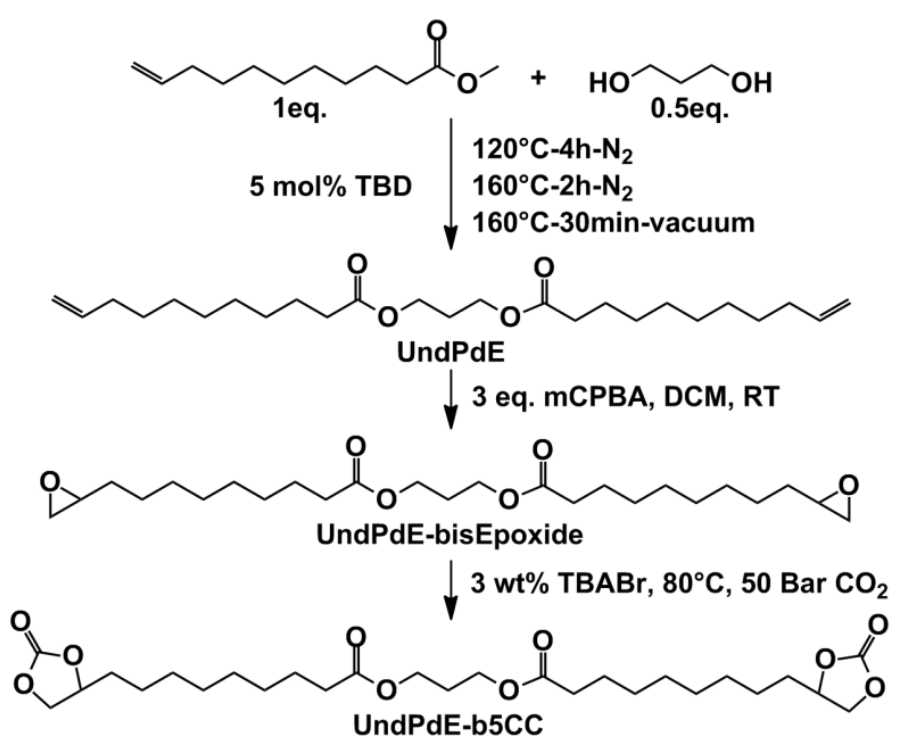

ESI Scheme 1-Synthetic pathway to UndPdE-b5CC from methyl undecenoate, 1,3-propanediol and $\mathrm{CO}_{2}$.

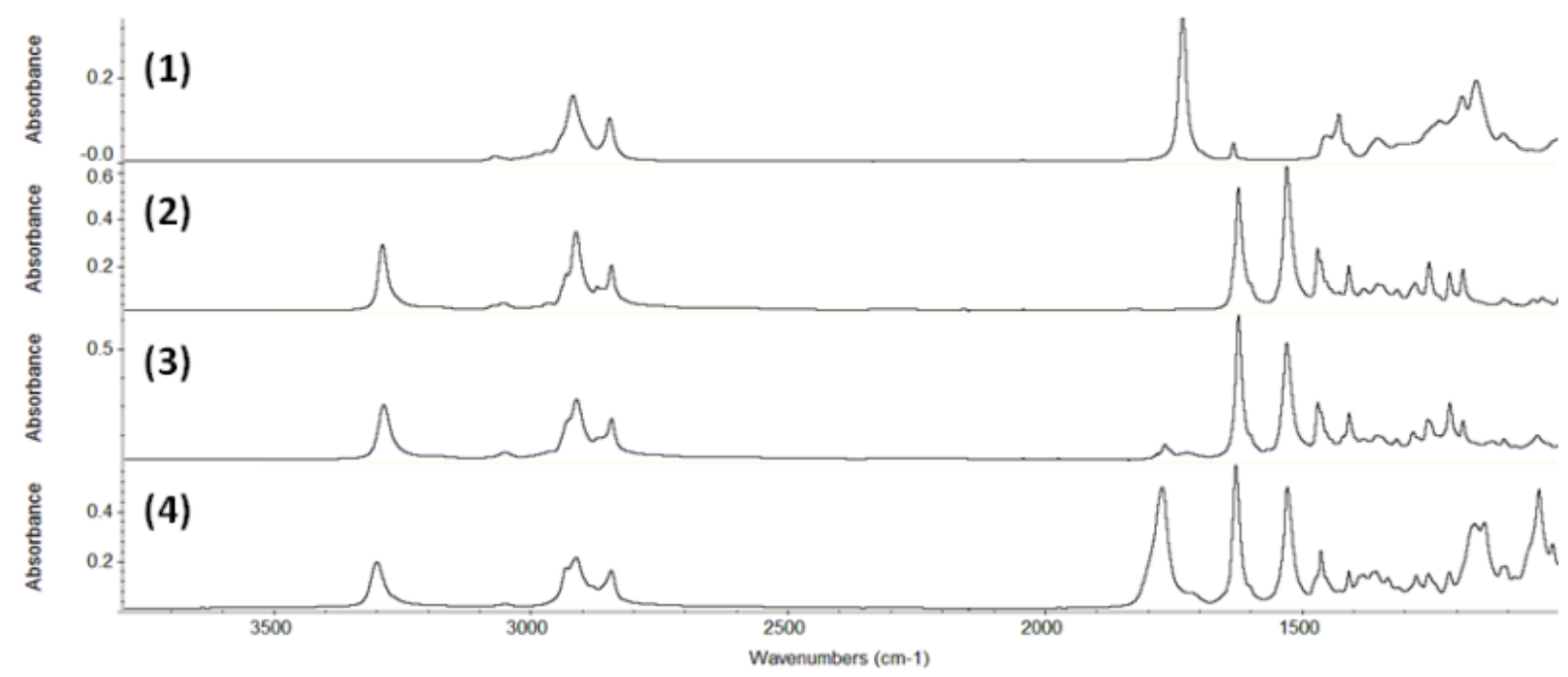

ESI Figure 1- Stacked FTIR-ATR spectra of (1) Methyl undecenoate, (2) UndBdA, (3) UndBdAbisEpoxide and (4) UndBdA-b5CC. 


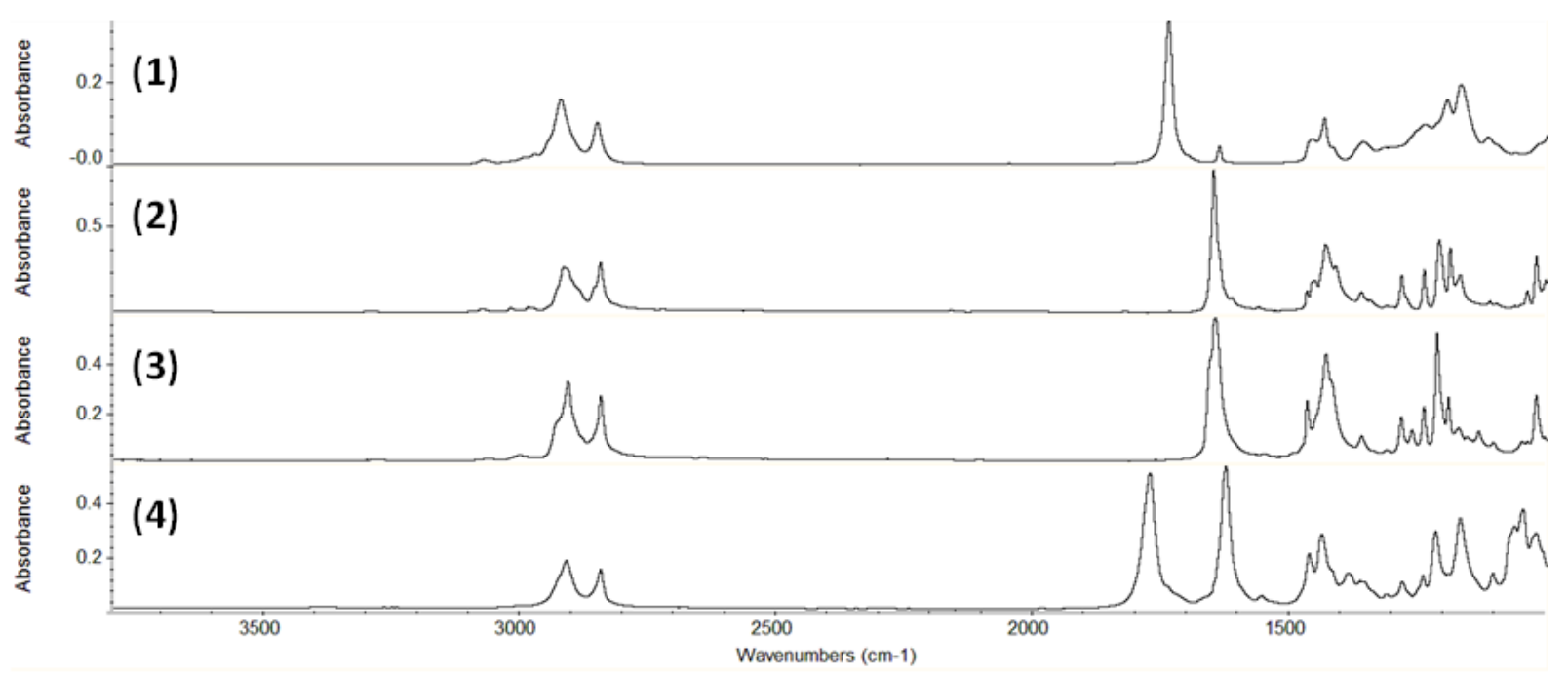

ESI Figure 1- Stacked FTIR-ATR spectra of (1) Methyl undecenoate, (2) UndPipdA, (3) UndPipdAbisEpoxide and (4) UndPipdA-b5CC.
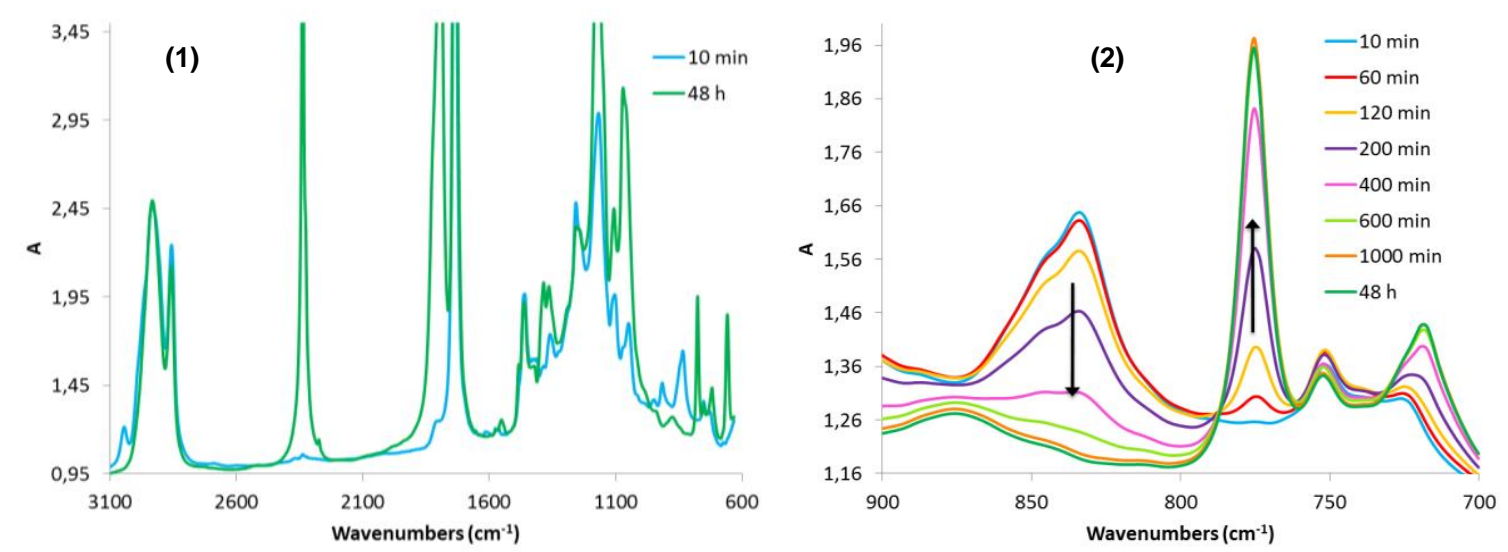

ESI Figure 3-Stacked FTIR spectra of the carbonation reaction of UndPdE-bisEpoxide at $80^{\circ} \mathrm{C}$ with $50 \mathrm{Bar}$ of $\mathrm{CO}_{2}$ and $3 \mathrm{wt} \% \mathrm{TBABr}(1)$ at $10 \mathrm{~min}$ and 48 hours and (2) at different reaction times with a focus between $900 \mathrm{~cm}^{-1}$ and $700 \mathrm{~cm}^{-1}$. 


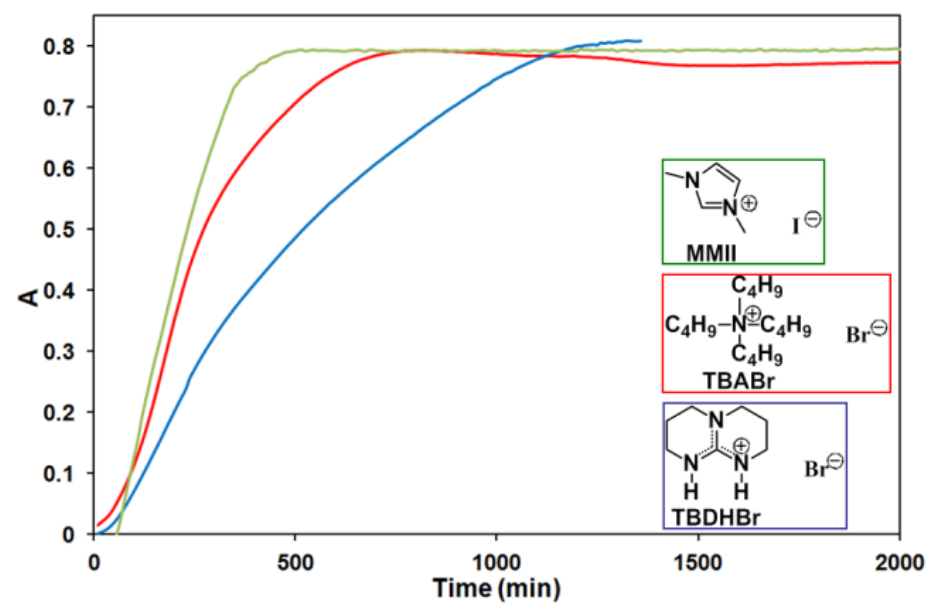

ESI Figure 2- Evolution of the absorbance of the band at $775 \mathrm{~cm}^{-1}$ during the carbonation reaction of UndPdE-bisEpoxide at $80^{\circ} \mathrm{C}$ with 50 Bar of $\mathrm{CO}_{2}$ and 3 wt\% catalyst.

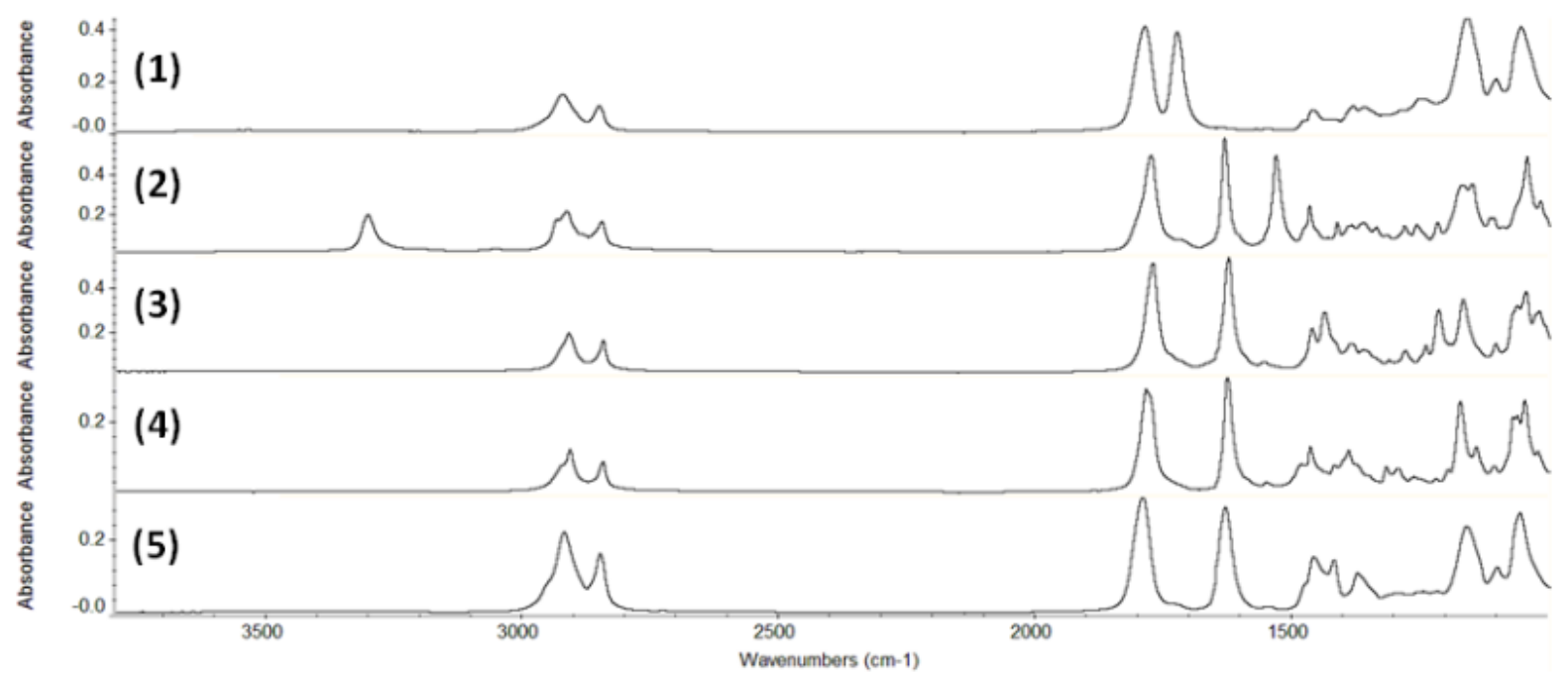

ESI Figure 5- Stacked FTIR-ATR spectra of (1) UndPdE-b5CC, (2) UndBdA-b5CC, (3) UndPipdAb5CC, (4) UndPMedA-b5CC and (5) UndDHexdA-b5CC. 
(1)

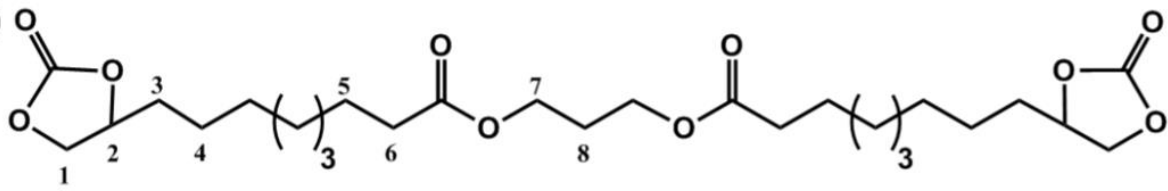

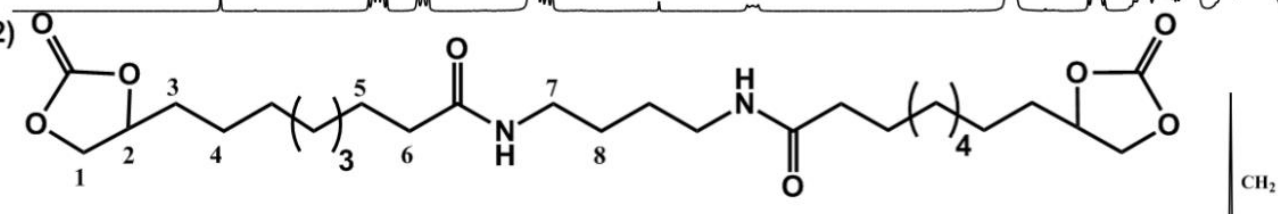

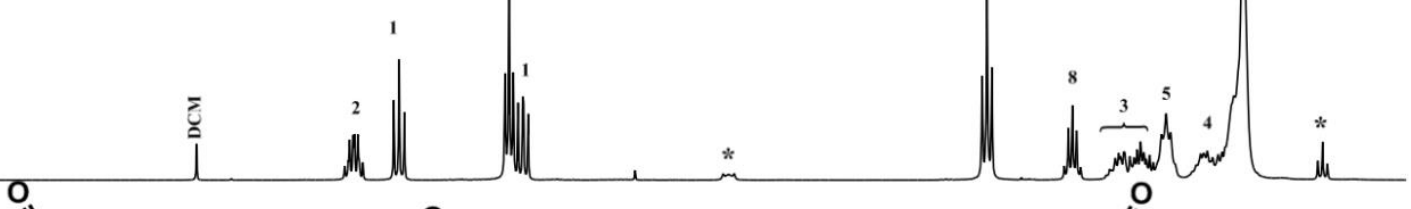<smiles>CC(CCC(C)(C)CC(=O)N1CCN(C(=O)CCCCCCCCC2COC(=O)O2)CC1)CC1CC(C)OC(=O)O1</smiles>

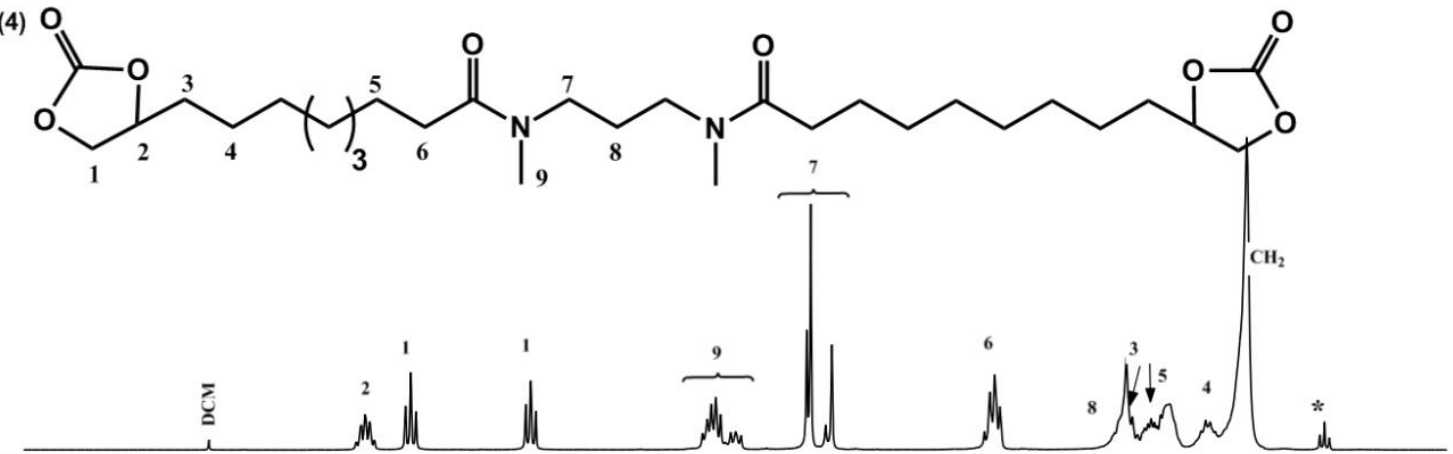
(5)

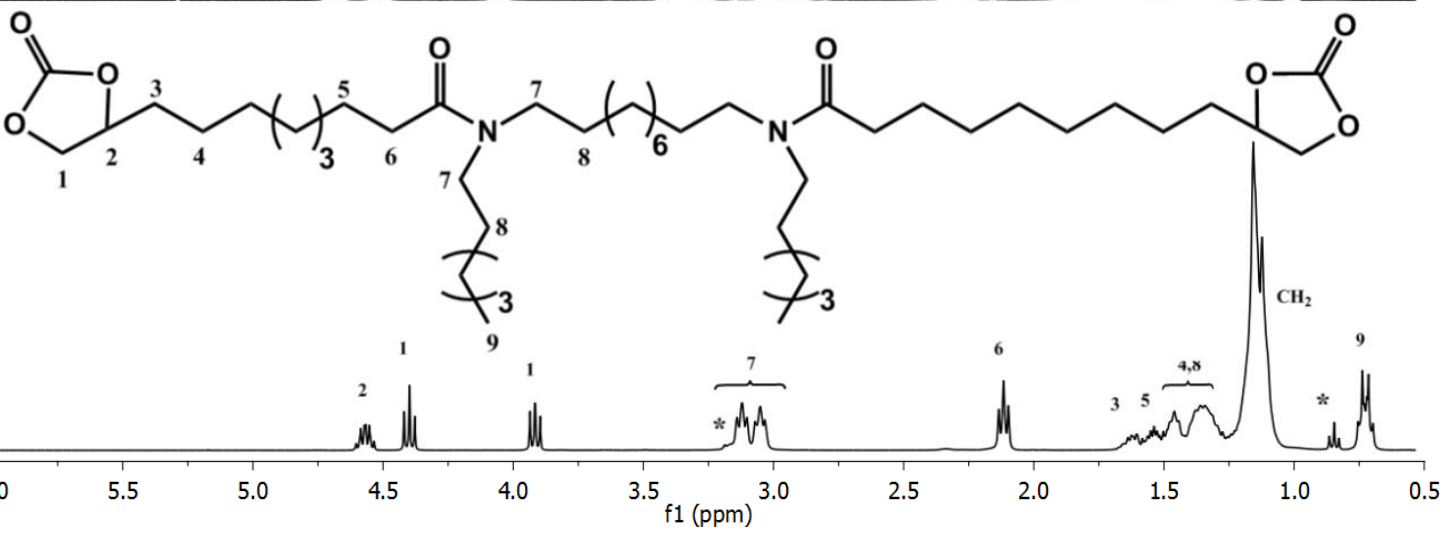

ESI Figure 6- Stacked ${ }^{1} H$ NMR spectra of (1) UndPdE-b5CC, (2) UndBdA-b5CC and (3) UndPipdAb5CC, (4) UndPMedA-b5CC and (5) UndDHexdA-b5CC. (*) TBABr. (Analyses in CDCl ${ }_{3}$ ) 


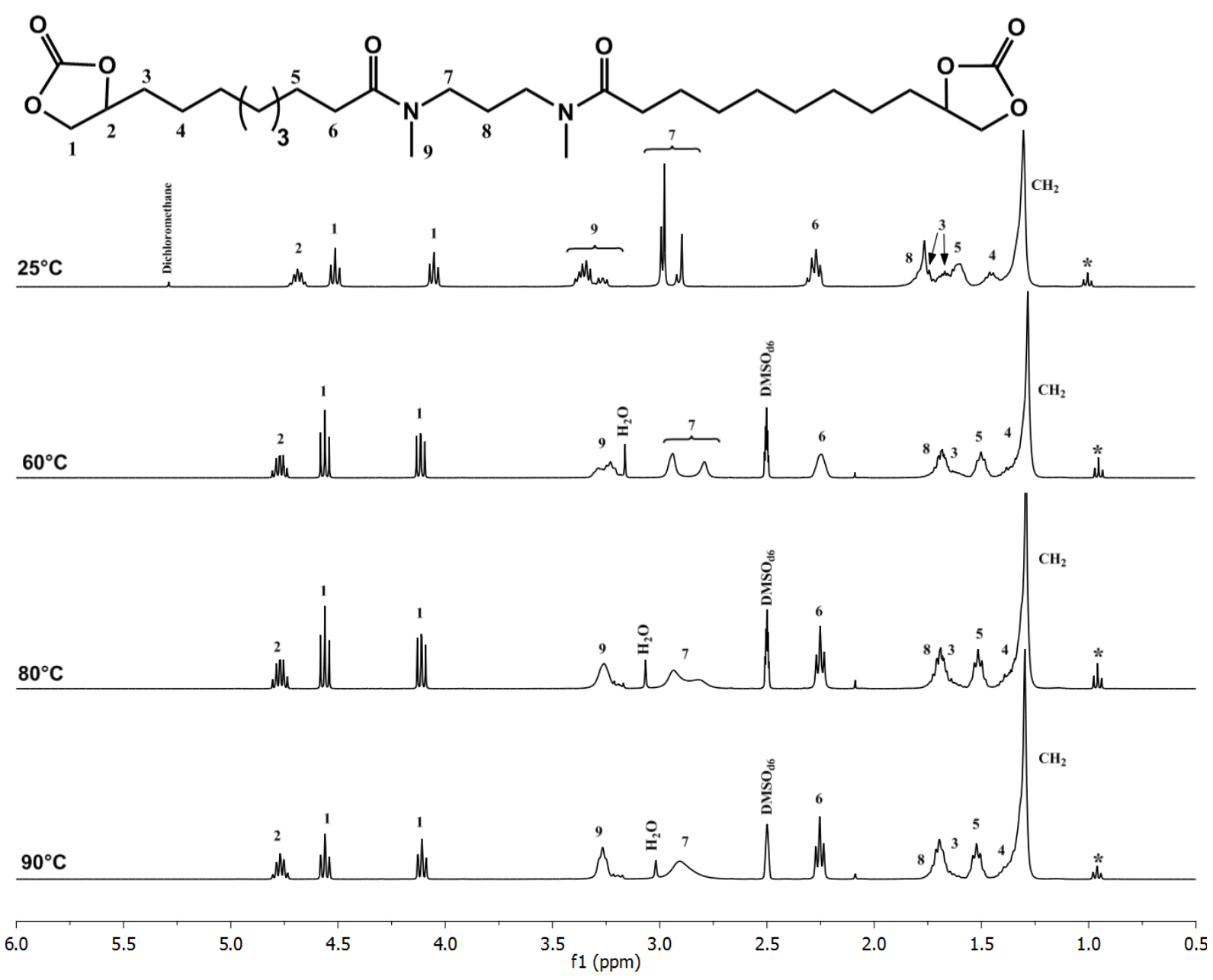

ESI Figure 7- ${ }^{l} \mathrm{H}$ NMR of UndPMedA-b5CC at $25^{\circ} \mathrm{C}$ (in $\mathrm{CDCl}_{3}$ ), $60^{\circ} \mathrm{C}, 80^{\circ} \mathrm{C}$ and $90^{\circ} \mathrm{C}$. (in DMSO-

d6)

ESI Table 1-Characterizations of the synthesized bis cyclic carbonates.

\begin{tabular}{cccc}
\hline Synthesized b5CC & Total yield (\%) & \% purity & $\mathbf{T}_{\mathbf{m}}\left({ }^{\circ} \mathbf{C}\right)^{3}$ \\
\hline UndPdE-b5CC & 68 & $99.1^{1}$ & $\mathrm{~L}$ \\
UndBdA-b5CC & 76 & nd & 137.4 \\
UndPipdA-b5CC & 56 & nd & 132.6 \\
UndPMedA-b5CC & 64 & $88.6^{2}$ & $102.5^{4}$ \\
UndDHexdA-b5CC & 44 & nd & $\mathrm{L}$
\end{tabular}

(1) Determined by SEC, (2) Determined by GC-FID and (3) Determined by DSC $10^{\circ} \mathrm{C} / \mathrm{min}$ under $\mathrm{N}_{2}$, (4) Crystallization while heating, $\mathrm{nd}=\mathrm{not}$ determined, $\mathrm{L}=$ liquid at room temperature. 


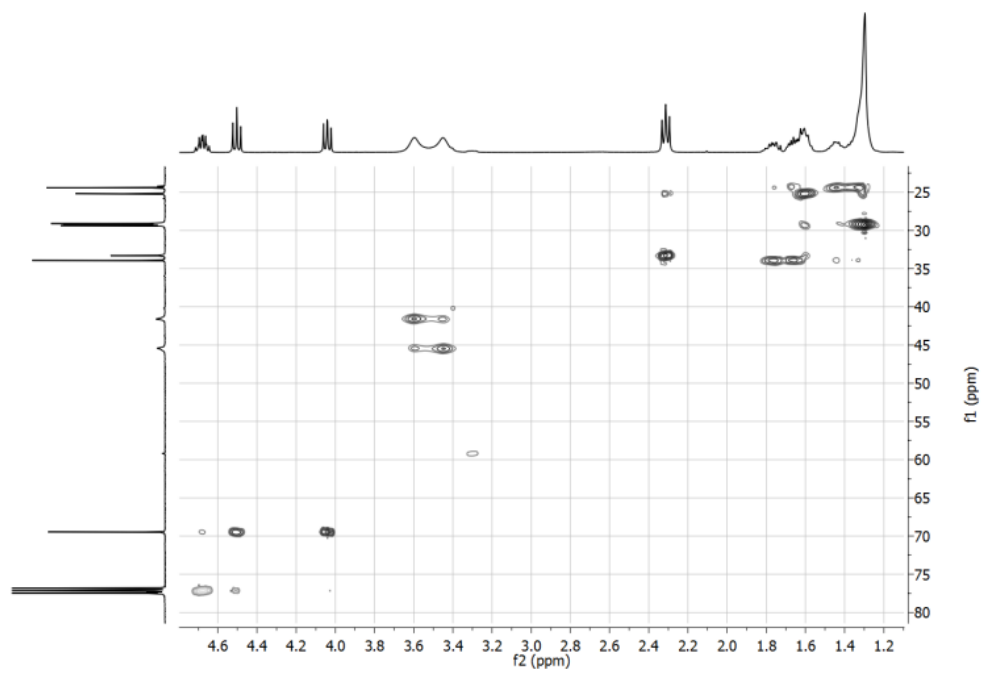

ESI Figure $8-{ }^{1} \mathrm{H}_{-}{ }^{13} \mathrm{C}$ HSQC-NMR of UndPipdA-b5CC. (Analysis in $\mathrm{CDCl}_{3}$ )

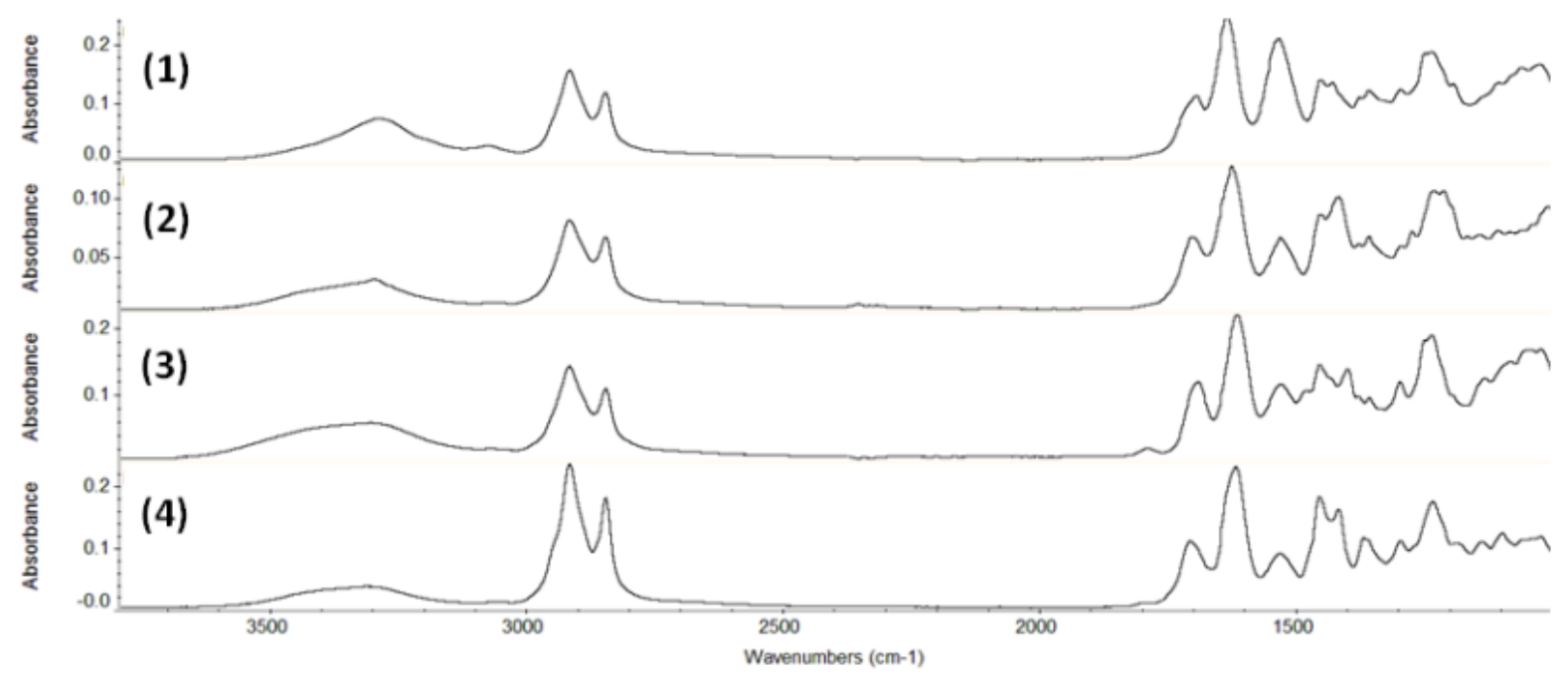

ESI Figure 9- Stacked FTIR-ATR spectra of PHU-BdA-1, PHU-PipdA-1, PHU-PMedA-1 and PHUDHexdA-1.

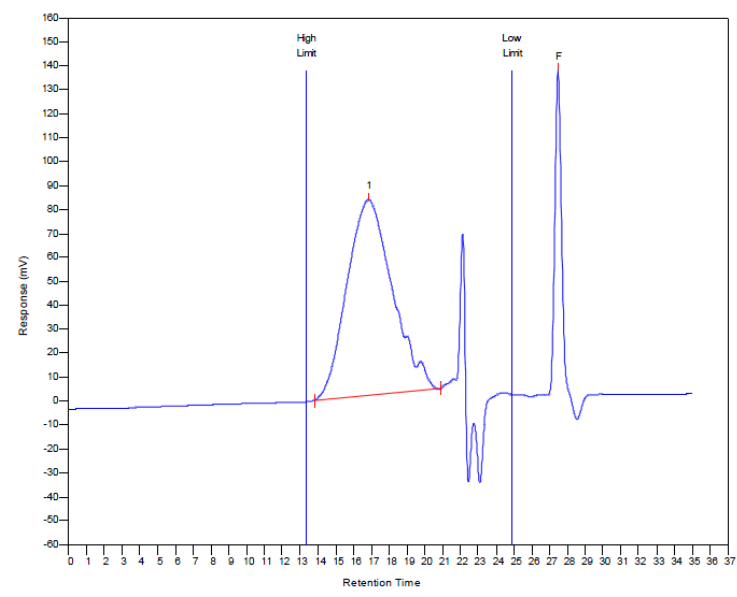

ESI Figure 10-SEC analysis of PHU-PMedA-2 (SEC in DMF with 1 wt\% LiBr - calibration PS standards). 


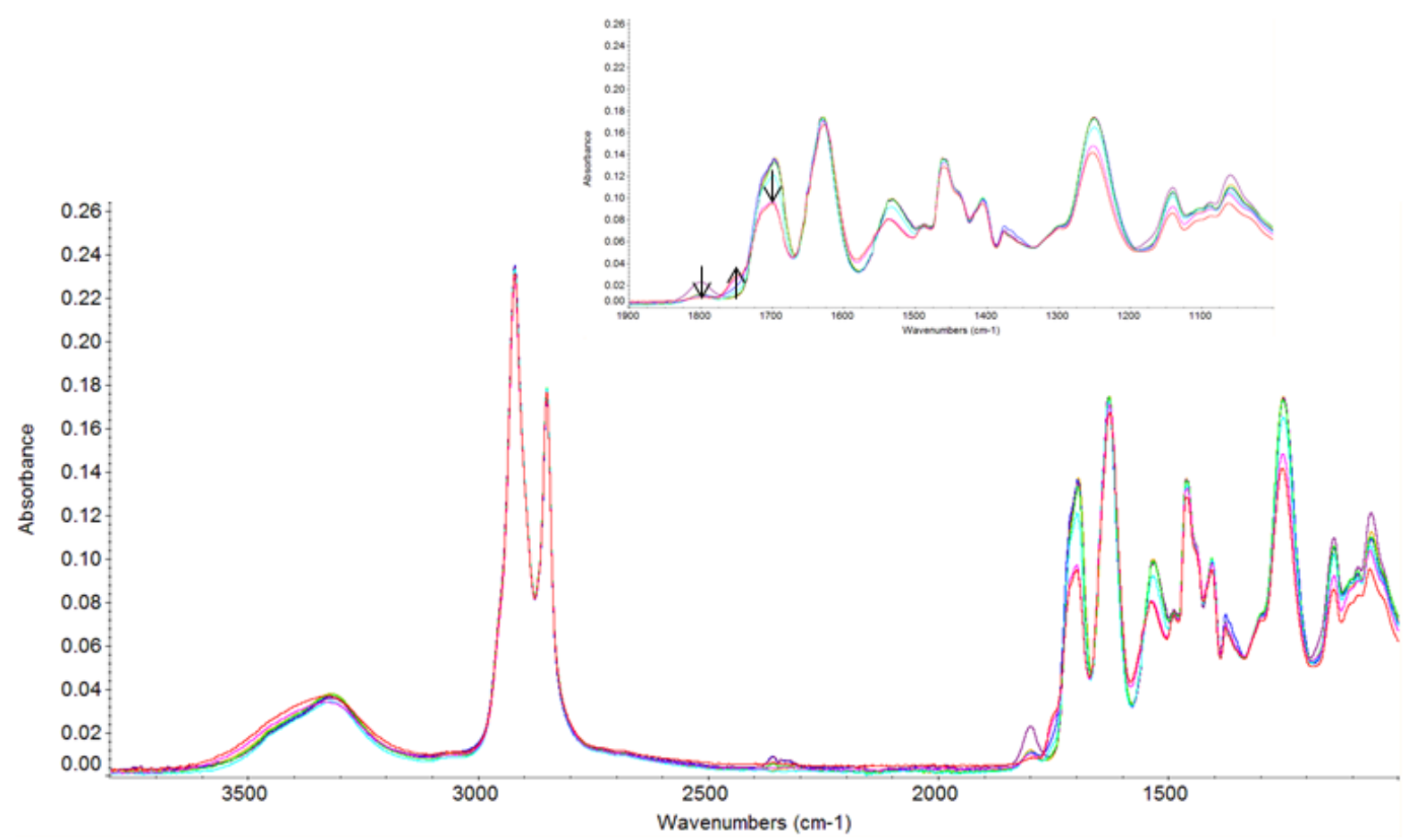

ESI Figure 11- FTIR-ATR evidence of the presence of side reactions during the polymerization in bulk at high temperature of PU-PMedA-2.

ESI Table 2-Decrease of the molar mass and of the glass transition temperature during the polymerization in bulk at high temperature of PU-PMedA-2.

\begin{tabular}{ccccc}
\hline Time (d) & $\bar{M}_{\mathrm{n}}\left(\mathrm{g} \cdot \mathrm{mol}^{-1}\right)$ & $\bar{M}_{\mathrm{w}}\left(\mathrm{g} \cdot \mathrm{mol}^{-1}\right)$ & $\bigoplus$ & $\mathrm{Tg}\left({ }^{\circ} \mathrm{C}\right)$ \\
\hline $1 \mathrm{~d}$ & 28100 & 41400 & 1.47 & -4.5 \\
6d & 28700 & 47500 & 1.66 & $\mathrm{nd}$ \\
$15 \mathrm{~d}$ & 17200 & 27800 & 1.61 & -11.5 \\
\hline
\end{tabular}

SEC in DMF with $1 \mathrm{wt} \% \mathrm{LiBr}$ - calibration PS standards.

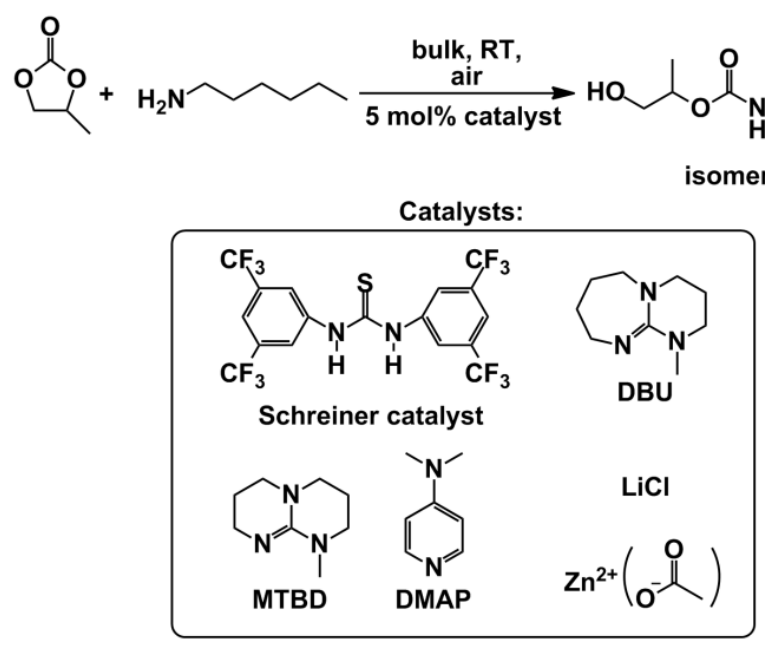

ESI Scheme 2-Model reaction of propylene carbonate and hexylamine as well as the various catalysts used. 


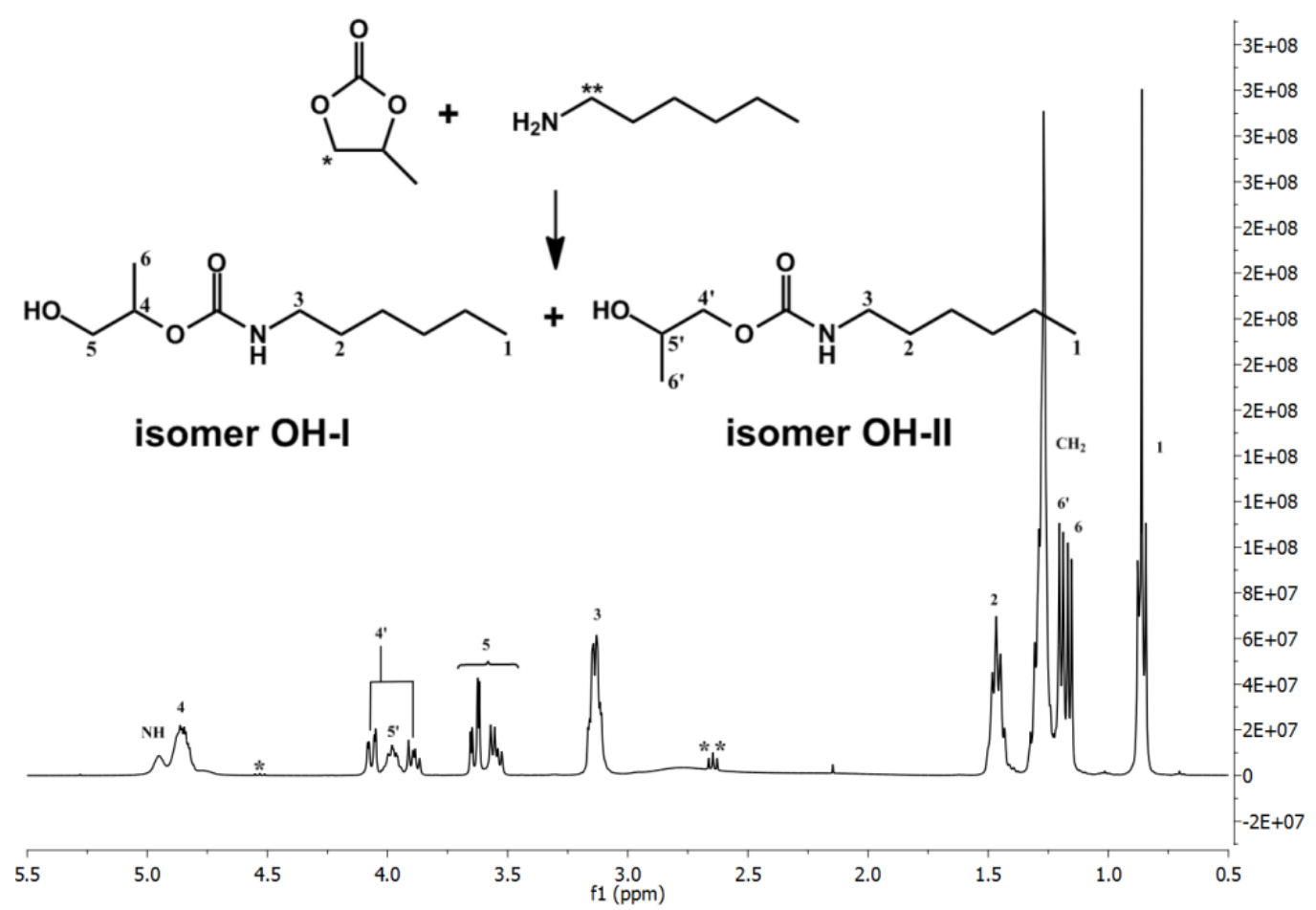

ESI Figure 12- ${ }^{1} H$ NMR of the reaction between propylene carbonate and hexylamine without catalyst at $R T$ after 11 days. (Analysis in $\mathrm{CDCl}_{3}$ )

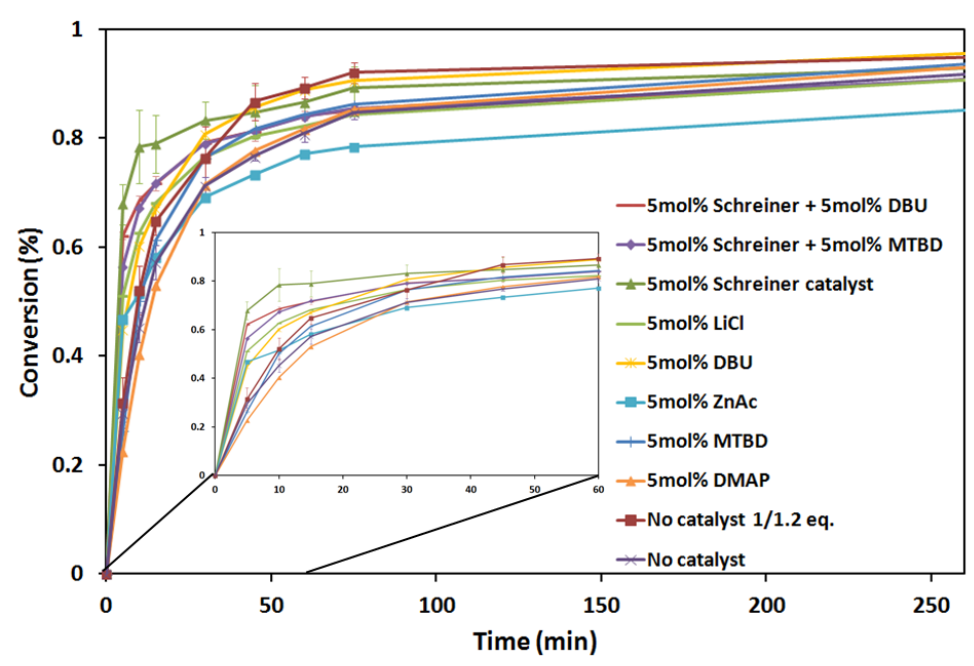

ESI Figure 13- Kinetic data of the model reaction with various catalysts at $25^{\circ} \mathrm{C}$ in bulk. 


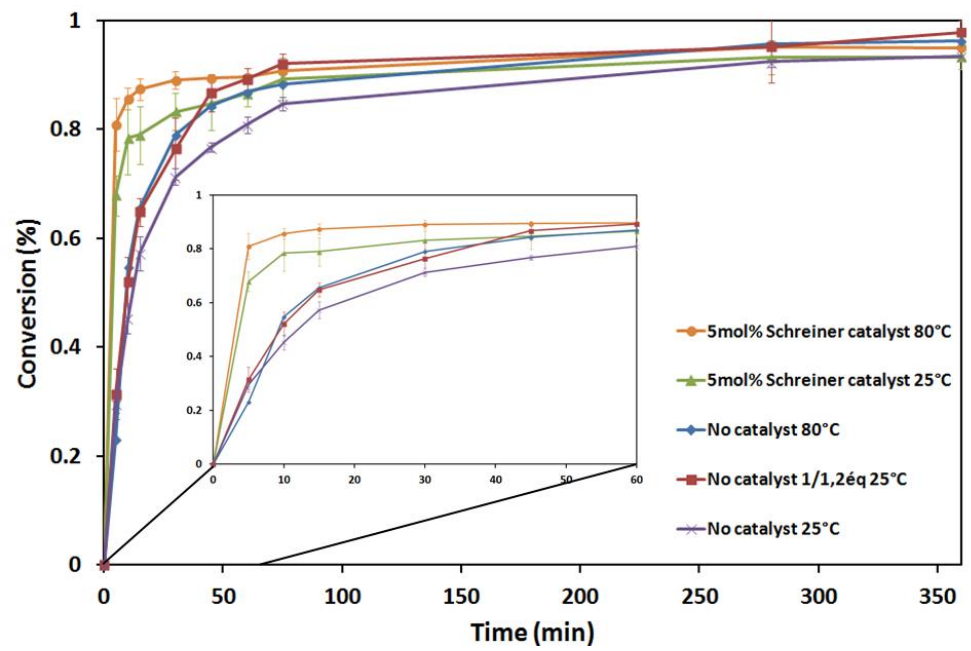

ESI Figure 14- Kinetic data of the model reaction with Schreiner catalyst at $25^{\circ} \mathrm{C}$ and $80^{\circ} \mathrm{C}$ in bulk.

ESI Table 3-Analyses of the reactions between 5CCMe and hexylamine with different catalysts in bulk at $R T$.

\begin{tabular}{ccc}
\hline Catalyst used & Catalyst quantity $(\mathrm{mol} \%)$ & Ratio OH I : OH \\
\hline No & $/$ & $58: 42$ \\
DMAP & 5 & $57: 43$ \\
MTBD & 5 & $58: 42$ \\
ZnAc & 5 & $60: 40$ \\
DBU & 5 & $53: 47$ \\
LiCl & 5 & $58: 42$ \\
Schreiner catalyst & 5 & $59: 41$ \\
Schreiner catalyst + MTBD & $5+5$ & $57: 43$ \\
Schreiner catalyst + DBU & $5+5$ & $50: 50$
\end{tabular}

(1) Calculated by ${ }^{1} \mathrm{H}$ NMR using the equation: $\% O H I=\frac{I_{O H I}}{I_{O H}+I_{O H} I} * 100$, where $\%$ OH I, IоH I and IoH II are the $\%$ of the product with primary hydroxyl and the integrations of the peaks corresponding to the product with primary and secondary hydroxyl respectively. 